\title{
Estimates of late Cenozoic climate change relevant to Earth surface processes in tectonically active orogens
}

\author{
Sebastian G. Mutz ${ }^{1}$, Todd A. Ehlers ${ }^{1}$, Martin Werner ${ }^{2}$, Gerrit Lohmann ${ }^{2}$, Christian Stepanek ${ }^{2}$, and \\ Jingmin $\mathbf{L i}^{1}{ }^{1, \mathrm{a}}$ \\ ${ }^{1}$ Department of Geosciences, University Tübingen, 72074 Tübingen, Germany \\ ${ }^{2}$ Department of Paleoclimate Dynamics, Alfred Wegener Institute, Helmholtz Centre for Polar and Marine \\ Research, 27570 Bremerhaven, Germany \\ anow at: Institute for Geography and Geology, University of Würzburg, Würzburg, 97074 Germany
}

Correspondence: Sebastian G. Mutz (sebastian.mutz@uni-tuebingen.de)

Received: 21 July 2017 - Discussion started: 16 August 2017

Revised: 2 March 2018 - Accepted: 9 March 2018 - Published: 6 April 2018

\begin{abstract}
The denudation history of active orogens is often interpreted in the context of modern climate gradients. Here we address the validity of this approach and ask what are the spatial and temporal variations in palaeoclimate for a latitudinally diverse range of active orogens? We do this using high-resolution (T159, ca. $80 \times 80 \mathrm{~km}$ at the Equator) palaeoclimate simulations from the ECHAM5 global atmospheric general circulation model and a statistical cluster analysis of climate over different orogens (Andes, Himalayas, SE Alaska, Pacific NW USA). Time periods and boundary conditions considered include the Pliocene (PLIO, $\sim 3 \mathrm{Ma}$ ), the Last Glacial Maximum (LGM, $\sim 21 \mathrm{ka}$ ), mid-Holocene $(\mathrm{MH}, \sim 6 \mathrm{ka})$, and pre-industrial (PI, reference year 1850). The regional simulated climates of each orogen are described by means of cluster analyses based on the variability in precipitation, $2 \mathrm{~m}$ air temperature, the intra-annual amplitude of these values, and monsoonal wind speeds where appropriate. Results indicate the largest differences in the PI climate existed for the LGM and PLIO climates in the form of widespread cooling and reduced precipitation in the LGM and warming and enhanced precipitation during the PLIO. The LGM climate shows the largest deviation in annual precipitation from the PI climate and shows enhanced precipitation in the temperate Andes and coastal regions for both SE Alaska and the US Pacific Northwest. Furthermore, LGM precipitation is reduced in the western Himalayas and enhanced in the eastern Himalayas, resulting in a shift of the wettest regional climates eastward along the orogen. The cluster-analysis results also suggest more climatic variability across latitudes east of the Andes in the PLIO climate than in other time slice experiments conducted here. Taken together, these results highlight significant changes in late Cenozoic regional climatology over the last $\sim 3 \mathrm{Myr}$. Comparison of simulated climate with proxy-based reconstructions for the MH and LGM reveal satisfactory to good performance of the model in reproducing precipitation changes, although in some cases discrepancies between neighbouring proxy observations highlight contradictions between proxy observations themselves. Finally, we document regions where the largest magnitudes of late Cenozoic changes in precipitation and temperature occur and offer the highest potential for future observational studies that quantify the impact of climate change on denudation and weathering rates.
\end{abstract}




\section{Introduction}

Interpretation of orogen denudation histories in the context of climate and tectonic interactions is often hampered by a paucity of terrestrial palaeoclimate proxy data needed to reconstruct spatial variations in palaeoclimate. While it is self-evident that palaeoclimate changes could influence palaeodenudation rates, it is not always self-evident what the magnitude of climate change over different geologic timescales is, or what geographic locations offer the greatest potential to investigate palaeoclimate impacts on denudation. Palaeoclimate reconstructions are particularly beneficial when denudation rates are determined using geo- and thermo-chronology techniques that integrate over timescales of $10^{3}-10^{6+}$ years (e.g. cosmogenic radionuclides or lowtemperature thermochronology; e.g. Kirchner et al., 2001; Schaller et al., 2002; Bookhagen et al., 2005; Moon et al., 2011; Thiede and Ehlers, 2013; Lease and Ehlers, 2013). However, few studies using denudation rate determination methods that integrate over longer timescales have access to information about past climate conditions that could influence these palaeodenudation rates. Palaeoclimate modelling offers an alternative approach to sparsely available proxy data for understanding the spatial and temporal variations in precipitation and temperature in response to changes in orography (e.g. Takahashi and Battisti, 2007a, b; Insel et al., 2010; Feng et al., 2013) and global climate change events (e.g. Salzmann et al., 2011; Jeffery et al., 2013). In this study, we characterise the climate at different times in the late Cenozoic and the magnitude of climate change for a range of active orogens. Our emphasis is on identifying changes in climate parameters relevant to weathering and catchment denudation to illustrate the potential importance of various global climate change events on surface processes.

Previous studies of orogen-scale climate change provide insight into how different tectonic or global climate change events influence regional climate change. For example, sensitivity experiments demonstrated significant changes in regional and global climate in response to landmass distribution and topography of the Andes, including changes in moisture transport, the north-south asymmetry of the Intertropical Convergence Zone (e.g. Takahashi and Battisti, 2007a; Insel et al., 2010), and (tropical) precipitation (Maroon et al., 2015, 2016). Another example is the regional and global climate changes induced by the Tibetan Plateau surface uplift due to its role as a physical obstacle to circulation (Raymo and Ruddiman, 1992; Kutzbach et al., 1993; Thomas, 1997; Bohner, 2006; Molnar et al., 2010; Boos and Kuang, 2010). The role of tectonic uplift in long-term regional and global climate change remains a focus of research and continues to be assessed with geologic datasets (e.g. Dettman et al., 2003; Caves, 2017; Kent-Corson et al., 2006; Lechler et al., 2013; Lechler and Niemi, 2011; Licht et al., 2017; Methner et al., 2016; Mulch et al., 2015, 2008; Pingel et al., 2016) and climate modelling (e.g. Kutzbach et al., 1989; Kutzbach et al., 1993; Zhisheng, 2001; Bohner, 2006; Takahashi and Battisti, 2007a; Ehlers and Poulsen, 2009; Insel et al., 2010; Boos and Kuang, 2010). Conversely, climate influences tectonic processes through erosion (e.g. Molnar and England, 1990; Whipple et al., 1999; Montgomery et al., 2001; Willett et al., 2006; Whipple, 2009). Quaternary climate change between glacial and interglacial conditions (e.g. Braconnot et al., 2007; Harrison et al., 2013) resulted in not only the growth and decay of glaciers and glacial erosion (e.g. Yanites and Ehlers, 2012; Herman et al., 2013; Valla et al., 2011) but also global changes in precipitation and temperature (e.g. Otto-Bliesner et al., 2006; Li et al., 2017) that could influence catchment denudation in non-glaciated environments (e.g. Schaller and Ehlers, 2006; Glotzbach et al., 2013; Marshall et al., 2015). These dynamics highlight the importance of investigating how much climate has changed over orogens that are the focus of studies of climate-tectonic interactions and their impact on erosion.

Despite recognition by previous studies that climate change events relevant to orogen denudation are prevalent throughout the late Cenozoic, few studies have critically evaluated how different climate change events may, or may not, have affected the orogen climatology, weathering, and erosion. Furthermore, recent controversy exists concerning the spatial and temporal scales over which geologic and geochemical observations can record climate-driven changes in weathering and erosion (e.g. Whipple, 2009; von Blanckenburg et al., 2015; Braun, 2016). For example, the previous studies highlight that although palaeoclimate impacts on denudation rates are evident in some regions and measurable with some approaches, they are not always present (or detectable) and the spatial and temporal scale of climate change influences our ability to record climate-sensitive denudation histories. This study contributes to our understanding of the interactions among climate, weathering, and erosion by bridging the gap between the palaeoclimatology and surface process communities by documenting the magnitude and distribution of climate change over tectonically active orogens.

Motivated by the need to better understand climate impacts on Earth surface processes, especially the denudation of orogens, we model palaeoclimate for four time slices in the late Cenozoic, use descriptive statistics to identify the extent of different regional climates, quantify changes in temperature and precipitation, and discuss the potential impacts on fluvial and/or hillslope erosion. In this study, we employ the ECHAM5 global atmospheric general circulation model (GCM) and document climate and climate change for time slices ranging between the Pliocene (PLIO, $\sim 3 \mathrm{Ma}$ ) to preindustrial (PI) times for the St Elias Mountains of southeastern Alaska, the US Pacific Northwest (Olympic and Cascade ranges), western South America (Andes), and South Asia (including parts of central and East Asia). Our approach is twofold and includes 
1. an empirical characterisation of palaeoclimates in these regions based on the covariance and spatial clustering of monthly precipitation and temperature, the monthly change in precipitation and temperature magnitude, and wind speeds where appropriate.

2. identification of changes in annual mean precipitation and temperature in selected regions for four time periods: (PLIO, Last Glacial Maximum (LGM), the midHolocene (MH), and PI) and subsequent validation of the simulated precipitation changes for the $\mathrm{MH}$ and LGM.

Our focus is on documenting climate and climate change in different locations with the intent of informing past and ongoing palaeodenudation studies of these regions. The results presented here also provide a means for future work to formulate testable hypotheses and investigations into whether or not regions of large palaeoclimate change produced a measurable signal in denudation rates or other Earth surface processes. More specifically, different aspects of the simulated palaeoclimate may be used as boundary conditions for vegetation and landscape evolution models, such as LPJ-GUESS and Landlab, to bridge the gap between climate change and quantitative estimates for Earth surface system responses. In this study, we intentionally refrain from applying predicted palaeoclimate changes to predict denudation rate changes. Such a prediction is beyond the scope of this study because a convincing (and meaningful) calculation of climate-driven transients in fluvial erosion (e.g. via the kinematic wave equation), variations in frost cracking intensity, or changes in hillslope sediment production and transport at the large regional scales considered here is not tractable within a single paper and instead is the focus of our ongoing work. Merited discussion of climatically induced changes in glacial erosion, as is important in the Cenozoic, is also beyond the scope of this study. Instead, our emphasis lies on providing and describing a consistently set-up GCM simulation framework for future investigations of Earth surface processes and identifying regions in which late Cenozoic climate changes potentially have a significant impact on fluvial and hillslope erosion.

\section{Methods: climate modelling and cluster analyses for climate characterisation}

\subsection{ECHAM5 simulations}

The global atmospheric GCM ECHAM5 (Roeckner et al., 2003) has been developed at the Max Planck Institute for Meteorology and is based on the spectral weather forecast model of the ECMWF (Simmons et al., 1989). In the context of palaeoclimate applications, the model has been used mostly at lower resolution (T31, ca. $3.75^{\circ} \times 3.75^{\circ}$; T63, ca. $1.9^{\circ} \times 1.9^{\circ}$ in the case of Feng et al., 2016, and T106 in the case of Li et al., 2017 and Feng and Poulsen, 2016). The studies performed are not limited to the last millennium (e.g. Jungclaus et al., 2010) but also include research in the field of both warmer and colder climates, at orbital (e.g. Gong et al., 2013; Lohmann et al., 2013; Pfeiffer and Lohmann, 2016; X. Zhang et al., 2013, 2014; Wei and Lohmann, 2012) and tectonic timescales (e.g. Knorr et al., 2011; Stepanek and Lohmann, 2012), and under anthropogenic influence (Gierz et al., 2015).

Here, the ECHAM5 simulations were conducted at a T159 spatial resolution (horizontal grid size ca. $80 \mathrm{~km} \times 80 \mathrm{~km}$ at the Equator) with 31 vertical levels (between the surface and $10 \mathrm{hPa}$ ). This high model resolution is admittedly not required for all of the climatological questions investigated in this study, and it should be noted that the skill of GCMs in predicting orographic precipitation remains limited at this scale (e.g. Meehl et al., 2007). However, simulations were conducted at this resolution so that future work can apply the results in combination with different dynamical and statistical downscaling methods to quantify changes at large catchment to orogen scales. The output frequency is relatively high (1 day) to enhance the usefulness of our simulations as input for landscape evolution and other models that may benefit from daily input. The simulations were conducted for five different time periods: present-day (PD), PI, MH, LGM, and PLIO.

A PD simulation (not shown here) was used to establish confidence in the model performance before conducting palaeosimulations and has been compared with the following observation-based datasets: European Centre for MediumRange Weather Forecasts (ECMWF) reanalyses (ERA40, Uppala et al., 2005), National Centers for Environmental Prediction and National Center for Atmospheric Research (NCEP/NCAR) reanalyses (Kalnay et al., 1996; Kistler et al., 2001), NCEP Regional Reanalysis (NARR; Mesinger et al., 2006), the Climate Research Unit (CRU) TS3.21 dataset (Harris et al., 2013), High Asia Refined Analysis (HAR30; Maussion et al., 2014), and the University of Delaware dataset (UDEL v3.01; Legates and Wilmott, 1990). (See Mutz et al., 2016, for a detailed comparison with a lowerresolution model).

The PI climate simulation is an ECHAM5 experiment with PI (reference year 1850) boundary conditions. Sea surface temperatures (SSTs) and sea ice concentration (SIC) are derived from transient coupled ocean-atmosphere simulations (Lorenz and Lohmann, 2004; Dietrich et al., 2013). Following Dietrich et al. (2013), greenhouse gas (GHG) concentrations $\left(\mathrm{CO}_{2}: 280 \mathrm{ppm}\right)$ are taken from ice-core-based reconstructions of $\mathrm{CO}_{2}$ (Etheridge et al., 1996), $\mathrm{CH}_{4}$ (Etheridge et al., 1998) and $\mathrm{N}_{2} \mathrm{O}$ (Sowers et al., 2003). Sea surface boundary conditions for the $\mathrm{MH}$ originate from a transient, low-resolution, coupled atmosphere-ocean simulation of the MH (6 ka) (Wei and Lohmann, 2012; Lohmann et al., 2013), where the $\mathrm{GHG}$ concentrations $\left(\mathrm{CO}_{2}: 280 \mathrm{ppm}\right)$ are taken from ice core reconstructions of GHGs by Etheridge et al. (1996, 1998) and Sowers et al. (2003). GHG concentra- 
tions for the LGM $\left(\mathrm{CO}_{2}: 185 \mathrm{ppm}\right)$ have been prescribed following Otto-Bliesner et al. (2006). Orbital parameters for the MH and LGM are set according to Dietrich et al. (2013) and Otto-Bliesner et al. (2006), respectively. LGM landsea distribution and ice sheet extent and thickness are set based on the PMIP III (Palaeoclimate Modelling Intercomparison Project, phase 3) guidelines (elaborated on by AbeOuchi et al., 2015). Following Schäfer-Neth and Paul (2003), SST and SIC for the LGM are based on GLAMAP (Sarnthein et al., 2003) and CLIMAP (CLIMAP project members, 1981) reconstructions for the Atlantic Ocean and Pacific and Indian oceans, respectively. Global MH and LGM vegetation is based on maps of plant functional types by the BIOME 6000 Palaeovegetation Mapping Project (Prentice et al., 2000; Harrison et al., 2001; Bigelow et al., 2003; Pickett et al., 2004) and model predictions by Arnold et al. (2009). Boundary conditions for the PLIO simulation, including GHG concentrations $\left(\mathrm{CO}_{2}: 405\right)$, orbital parameters and surface conditions (SST, SIC, sea land mask, topography, and ice cover) are taken from the PRISM (Pliocene Research, Interpretation and Synoptic Mapping) project (Haywood et al., 2010; Sohl et al., 2009; Dowsett et al., 2010), specifically PRISM3D. The PLIO vegetation boundary condition was created by converting the PRISM vegetation reconstruction to the JSBACH plant functional types as described by Stepanek and Lohmann (2012), but the built-in land surface scheme was used.

SST reconstructions can be used as an interface between oceans and atmosphere (e.g. Li et al., 2017) instead of conducting the computationally more expensive fully coupled atmosphere-ocean GCM experiments. While the use of SST climatologies comes at the cost of capturing decadal-scale variability, and the results are ultimately biased towards the SST reconstructions the model is forced with; the simulated climate more quickly reaches an equilibrium state and the means of atmospheric variables used in this study do no change significantly after the relatively short spin-up period. The palaeoclimate simulations (PI, MH, LGM, PLIO) using ECHAM5 are therefore carried out for 17 model years, of which the first 2 years are used for model spinup. The monthly long-term averages (multi-year means for individual months) for precipitation, temperature, and precipitation and temperature amplitude, i.e. the mean difference between the hottest and coldest months, have been calculated from the following 15 model years for the analysis presented below.

For further comparison between the simulations, the investigated regions were subdivided (Fig. 1). Western South America was subdivided into four regions: parts of tropical South America $\left(80-60^{\circ} \mathrm{W}, 23.5-5^{\circ} \mathrm{S}\right)$; temperate South America $\left(80-60^{\circ} \mathrm{W}, 50-23.5^{\circ} \mathrm{S}\right)$; tropical Andes $\left(80-60^{\circ} \mathrm{W}\right.$, 23.5-5 $\mathrm{S}$; high-pass filtered), i.e. most of the Peruvian Andes, Bolivian Andes, and northernmost Chilean Andes; and temperate Andes $\left(80-60^{\circ} \mathrm{W}, 50-23.5^{\circ} \mathrm{S}\right.$, high-pass filtered). South Asia was subdivided into three regions: tropical South Asia $\left(40-120^{\circ} \mathrm{E}, 0-23.5^{\circ} \mathrm{N}\right)$, temperate South Asia $\left(40-120^{\circ}\right.$ E, $\left.23.5-60^{\circ} \mathrm{N}\right)$, and high-altitude South Asia (40$120^{\circ} \mathrm{E}, 0-60^{\circ} \mathrm{N}$; high-pass filtered).

Our approach of using a single GCM (ECHAM5) for our analysis is motivated by, and differs from, previous studies where inter-model variability exists from the use of different GCMs due to different parameterisations in each model. The variability in previous inter-model GCM comparisons exists despite the use of the same forcings (e.g. see results highlighted in IPCC AR5). Similarities identified between these palaeoclimate simulations conducted with different GCMs using similar boundary conditions can establish confidence in the models when in agreement with proxy reconstructions. However, differences identified in inter-model GCM comparisons highlight biases by all or specific GCMs, or reveal sensitivities to one changed parameter, such as model resolution. Given these limitations of GCM modelling, we present in this study a comparison of a suite of ECHAM5 simulations to proxy-based reconstructions (where possible) and, to a lesser degree, comment on general agreement or disagreement of our ECHAM5 results with other modelling studies. A detailed inter-model comparison of our results with other GCMs is beyond the scope of this study and better suited for a different study in a journal with a different focus and audience. Rather, by using the same GCM and identical resolution for the time slice experiments, we reduce the number of parameters (or model parameterisations) varying between simulations and thereby remove potential sources of error or uncertainty that would otherwise have to be considered when comparing output from different models with different parameterisations of processes, model resolution, and in some cases model forcings (boundary conditions). Nevertheless, the reader is advised to use these model results with the GCM's shortcoming and uncertainties in boundary condition reconstructions in mind. For example, precipitation results may require dynamical or statistical downscaling to increase accuracy where higher-resolution precipitation fields are required. Furthermore, readers are advised to familiarise themselves with the palaeogeography reconstruction initiatives and associated uncertainties. For example, while Pliocene ice sheet volume can be estimated, big uncertainties pertaining to their locations remain (Haywood et al., 2010).

\subsection{Cluster analysis to document temporal and spatial changes in climatology}

The aim of the clustering approach is to group climate model surface grid boxes together based on similarities in climate. Cluster analyses are statistical tools that allow elements (i) to be grouped by similarities in the elements' attributes. In this study, those elements are spatial units, the elements' attributes are values from different climatic variables, and the measure of similarity is given by a statistical distance. The four basic variables used as climatic attributes of these spatial elements are near-surface $(2 \mathrm{~m})$ air temperature, seasonal $2 \mathrm{~m}$ air temperature amplitude, precipitation rate, and seasonal 

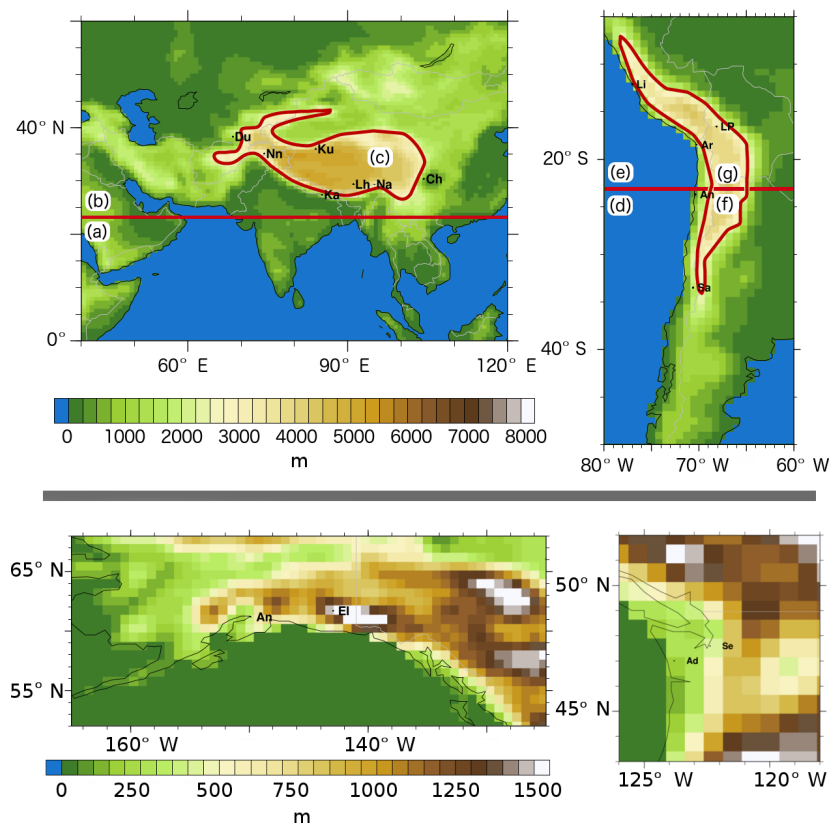

Figure 1. Topography for regions (a) tropical South Asia, (b) temperate South Asia, (c) high-altitude South Asia, (d) temperate South America, (e) tropical South America, (f) the temperate Andes, and (g) the tropical Andes, SE Alaska, and Cascadia.

precipitation rate amplitude. Since monsoonal winds are a dominant feature of the climate in the South Asia region, near-surface $(10 \mathrm{~m})$ speeds of $u$ wind and $v$ wind (zonal and meridional wind components, respectively) during the monsoon season (July) and outside the monsoon season (January) are included as additional variables in our analysis of that region. Similarly, $u$-wind and $v$-wind speeds during (January) and outside (July) the monsoon season in South America are added to the list of considered variables to take into account the South American Monsoon System (SASM) in the cluster analysis for this region. The long-term monthly means of those variables are used in a hierarchical clustering method, followed by a non-hierarchical $k$-means correction with randomised regroupment (Mutz et al., 2016; Wilks, 2011; Paeth, 2004; Bahrenberg et al., 1992).

The hierarchical part of the clustering procedure starts with as many clusters as there are elements (ni), then iteratively combines the most similar clusters to form a new cluster using centroids for the linkage procedure for clusters containing multiple elements. The procedure is continued until the desired number of clusters $(k)$ is reached. One disadvantage of a pure hierarchical approach is that elements cannot be recategorised once they are assigned to a cluster, even though the addition of new elements to existing clusters changes the clusters' defining attributes and could warrant a recategorisation of elements. We address this problem by implementation of a (non-hierarchical) $k$-means clustering correction (e.g. Paeth, 2004). Elements are recategorised based on the multivariate centroids determined by the hierarchical cluster analysis in order to minimise the sum of deviations from the cluster centroids. The Mahalanobis distance (e.g. Wilks, 2011) is used as a measure of similarity or distance between the cluster centroids since it is a statistical distance and thus not sensitive to different variable units. The Mahalanobis distance also accounts for possible multi-collinearity between variables.

The end results of the cluster analyses are subdivisions of the climate in the investigated regions into $k$ subdomains or clusters based on multiple climate variables. The regionspecific $k$ has to be prescribed before the analyses. A large $k$ may result in redundant additional clusters describing very similar climates, thereby defeating the purpose of the analysis to identify and describe the dominant, distinctly different climates in the region and their geographical coverage. Since it is not possible to know a priori the ideal number of clusters, $k$ was varied between 3 and 10 for each region and the results presented below identify the optimal number of visibly distinctly different clusters from the analysis. Optimal $k$ was determined by assessing the distinctiveness and similarities between the climate clusters in the systematic process of increasing $k$ from 3 to 10 . Once an increase in $k$ no longer resulted in the addition of another cluster that was climatologically distinctly different from the others, and instead resulted in at least two similar clusters, $k$ of the previous iteration was chosen as the optimal $k$ for the region.

The cluster analysis ultimately results in a description of the geographical extent of a climate (cluster) characterised by a certain combination of mean values for each of the variables associated with the climate. For example, climate cluster 1 may be the most tropical climate in a region and thus be characterised by high precipitation values, high temperature values, and low seasonal temperature amplitude. Each of the results (consisting of the geographical extent of climates and mean vectors describing the climate) can be viewed as an optimal classification for the specific region and time. It serves primarily as a means for providing an overview of the climate in each of the regions at different times, reduces dimensionality of the raw simulation output, and identifies regions of climatic homogeneity that are difficult to notice by viewing simple maps of each climate variable. Its synoptic purpose is similar to that of the widely known Köppen-Geiger classification scheme (Peel et al., 2007), but we allow for optimal classification rather than prescribe classes, and our selection of variables is more restricted and made in accordance with the focus of this study.

\section{Results}

Results from our analysis are first presented for general changes in global temperature and precipitation for the different time slices (Figs. 2, 3), which is then followed by an analysis of changes in the climatology of selected orogens. 
A more detailed description of temperature and precipitation changes in our selected orogens is presented in subsequent subsections (Fig. 4 and following). All differences in climatology are expressed relative to the PI control run. Changes relative to the PI rather than PD conditions are presented to avoid interpreting an anthropogenic bias in the results and focusing instead on pre-anthropogenic variations in climate. For brevity, near-surface $(2 \mathrm{~m})$ air temperature and total precipitation rate are referred to as temperature and precipitation.

\subsection{Global differences in mean annual temperature}

This section describes the differences between simulated MH, LGM, and PLIO annual mean temperature anomalies with respect to PI shown in Fig. 2b, and PI temperature absolute values shown in Fig. 2a. Most temperature differences between the PI and MH climate are within -1 to $1^{\circ} \mathrm{C}$. Exceptions to this are the Hudson Bay, Weddell Sea, and Ross Sea regions, which experience warming of $1-3,1-5$, and 1$9^{\circ} \mathrm{C}$, respectively. Continental warming is mostly restricted to low-altitude South America, Finland, western Russia, the Arabian peninsula $\left(1-3^{\circ} \mathrm{C}\right)$, and subtropical North Africa (1$5^{\circ} \mathrm{C}$ ). Simulation results show that LGM and PLIO annual mean temperature deviate from the PI means the most. The global PLIO warming and LGM cooling trends are mostly uniform in direction, but the magnitude varies regionally. The strongest LGM cooling is concentrated in regions where the greatest change in ice extent occurs (as indicated in Fig. 2), i.e. Canada, Greenland, the North Atlantic, northern Europe, and Antarctica. Central Alaska shows no temperature changes, whereas coastal southern Alaska experiences cooling of $\leq 9^{\circ} \mathrm{C}$. Cooling in the US Pacific Northwest is uniform and between 11 and $13{ }^{\circ} \mathrm{C}$. Most of high-altitude South America experiences mild cooling of $1-3^{\circ} \mathrm{C}, 3-5^{\circ} \mathrm{C}$ in the central Andes, and $\leq 9^{\circ} \mathrm{C}$ in the south. Along the Himalayan orogen, LGM temperature values are $5-7^{\circ} \mathrm{C}$ below PI values. Much of central Asia and the Tibetan Plateau cools by 3$5^{\circ} \mathrm{C}$, and most of India, low-altitude China, and South East Asia cools by $1-3^{\circ} \mathrm{C}$.

In the PLIO climate, parts of Antarctica, Greenland, and the Greenland Sea experience the greatest temperature increase $\left(\leq 19^{\circ} \mathrm{C}\right)$. Most of southern Alaska warms by $1-5$ and $\leq 9^{\circ} \mathrm{C}$ near McCarthy, Alaska. The US Pacific Northwest warms by $1-5^{\circ} \mathrm{C}$. The strongest warming in South America is concentrated at the Pacific west coast and the Andes (1$9^{\circ} \mathrm{C}$ ), specifically between Lima and Chiclayo, and along the Chilean-Argentinian Andes south of Bolivia $\left(\leq 9^{\circ} \mathrm{C}\right)$. Parts of low-altitude South America to the immediate east of the Andes experience cooling of $1-5^{\circ} \mathrm{C}$. The Himalayan orogen warms by $3-9^{\circ} \mathrm{C}$, whereas Myanmar, Bangladesh, Nepal, northern India, and northeastern Pakistan cool by $1-9^{\circ} \mathrm{C}$. (a) Mean annual temperature (PI)

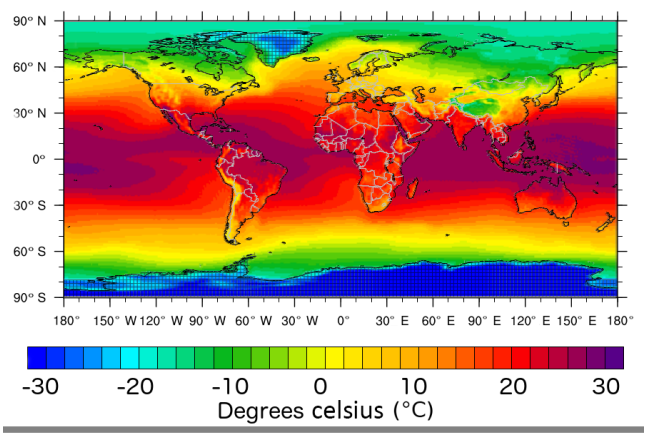

(b) Temperature difference $(\mathrm{MH}-\mathrm{PI})$

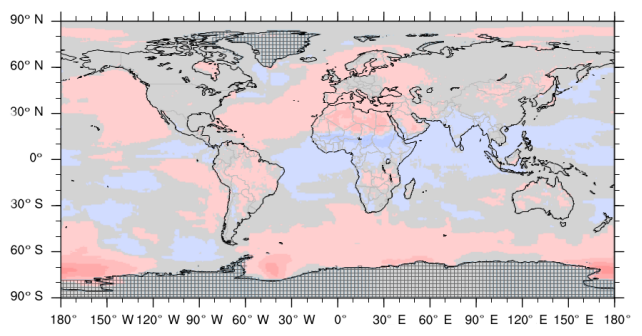

Temperature difference (LGM - PI)

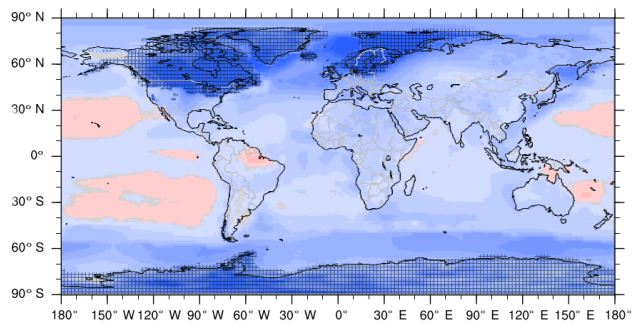

Temperature difference (PLIO - PI)

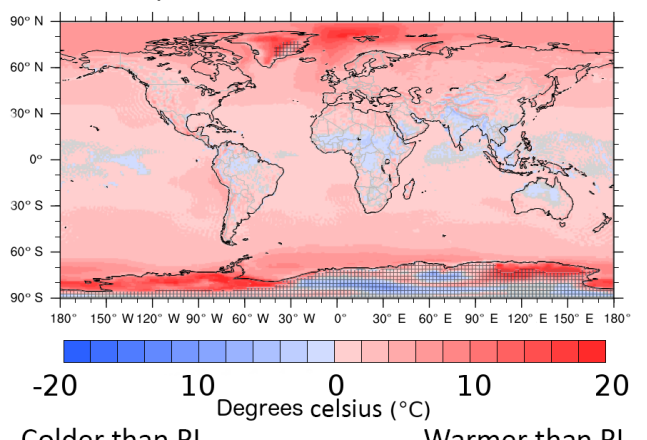

Colder than $\mathrm{P}$

Warmer than PI

Ice cover

Figure 2. Global PI annual mean near-surface temperatures (a) and deviations of MH, LGM, and PLIO annual mean near-surface temperatures from PI values (b). Units are ${ }^{\circ} \mathrm{C}$ and insignificant $(p<99 \%)$ differences (as determined by a $t$ test) are greyed out. 


\subsection{Global differences in mean annual precipitation}

Notable differences occur between simulated MH, LGM, and PLIO annual mean precipitation anomalies with respect to PI shown in Fig. $3 \mathrm{~b}$ and the PI precipitation absolute values shown in Fig. 3a. Of these, $\mathrm{MH}$ precipitation deviates the least from PI values. The differences between $\mathrm{MH}$ and PI precipitation on land appear to be largest in northern tropical Africa (increase $\leq 1200 \mathrm{~mm} \mathrm{a}^{-1}$ ), along the Himalayan orogen (increase $\leq 2000 \mathrm{~mm} \mathrm{a}^{-1}$ ), and in central Indian states (decrease) $\leq 500 \mathrm{~mm}$. The biggest differences in western South America are precipitation increases in central Chile between Santiago and Puerto Montt. The LGM climate shows the largest deviation in annual precipitation from the PI climate, and precipitation on land mostly decreases. Exceptions are increases in precipitation rates in North American coastal regions, especially in coastal southern Alaska $\left(\leq 2300 \mathrm{~mm} \mathrm{a}^{-1}\right)$ and the US Pacific Northwest $\left(\leq 1700 \mathrm{~mm} \mathrm{a}^{-1}\right)$. Further exceptions are precipitation increases in low-altitude regions immediately east of the Peruvian Andes $\left(\leq 1800 \mathrm{~mm} \mathrm{a}^{-1}\right)$, central Bolivia $\left(\leq 1000 \mathrm{~mm} \mathrm{a}^{-1}\right)$, most of Chile $\left(\leq 1000 \mathrm{~mm} \mathrm{a}^{-1}\right)$, and northeastern India $\left(\leq 1900 \mathrm{~mm} \mathrm{a}^{-1}\right)$. Regions of notable precipitation decrease are northern Brazil $\left(\leq 1700 \mathrm{~mm} \mathrm{a}^{-1}\right)$, southernmost Chile and Argentina $\left(\leq 1900 \mathrm{~mm} \mathrm{a}^{-1}\right)$, coastal south Peru $\left(\leq 700 \mathrm{~mm} \mathrm{a}^{-1}\right)$, central India $\left(\leq 2300 \mathrm{~mm} \mathrm{a}^{-1}\right)$, and Nepal $\left(\leq 1600 \mathrm{~mm} \mathrm{a}^{-1}\right)$.

Most of the precipitation on land in the PLIO climate is higher than that in the PI climate. Precipitation is enhanced by ca. $100-200 \mathrm{~mm} \mathrm{a}^{-1}$ in most of the Atacama Desert, by $\leq 1700 \mathrm{~mm} \mathrm{a}^{-1}$ south of the Himalayan orogen, and by $\leq 1400 \mathrm{~mm} \mathrm{a}^{-1}$ in tropical South America. Precipitation significantly decreases in central Peru $(\leq 2600 \mathrm{~mm})$, southernmost Chile ( $\leq 2600 \mathrm{~mm}$ ), and from eastern Nepal to northernmost northeastern India $(\leq 2500 \mathrm{~mm})$.

\subsection{Palaeoclimate characterisation from the cluster analysis and changes in regional climatology}

In addition to the global changes described above, the PLIO to PI regional climatology changes substantially in the four investigated regions of South Asia (Sect. 3.3.1), the Andes (Sect. 3.3.2), southern Alaska (Sect. 3.3.3), and the Cascade Range (Sect. 3.3.4). Each climate cluster defines a separate distinct climate that is characterised by the mean values of the different climate variables used in the analysis. The clusters are calculated by taking the arithmetic means of all the values (climatic means) calculated for the grid boxes within each region. The regional climates are referred to by their cluster number $\mathrm{C}_{1}, \mathrm{C}_{2}, \ldots, \mathrm{C}_{k}$, where $k$ is the number of clusters specified for the region. The clusters for specific palaeoclimates are mentioned in the text as $\mathrm{C}_{i[t]}$, where $i$ corresponds to the cluster number $(i=1, \ldots, k)$ and $t$ to the simulation time period ( $t=\mathrm{PI}, \mathrm{MH}, \mathrm{LGM}, \mathrm{PLIO}$ ). The descriptions first highlight the similarities and then the differences in (a) Mean annual precipitation (PI)

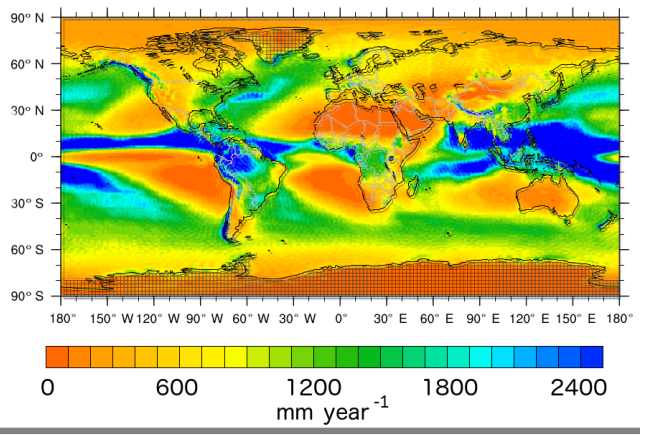

(b)

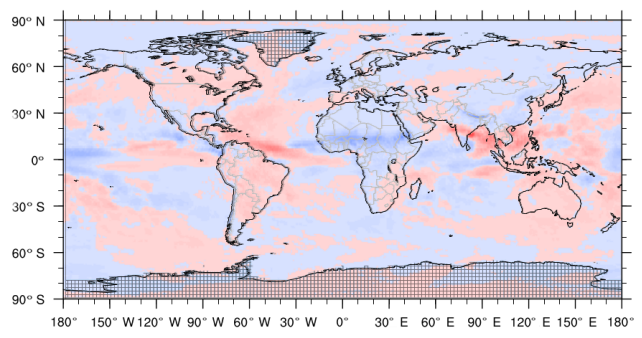

Precipitation difference (LGM -PI)

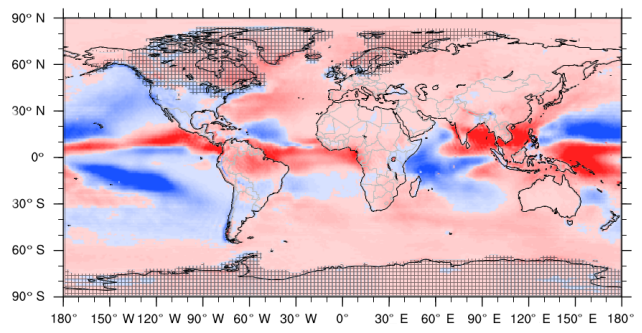

Precipitation difference (PLIO - PI)

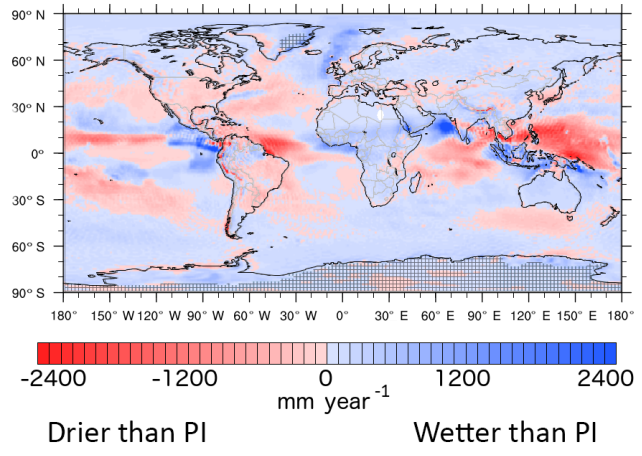

Ice cover

Figure 3. Global PI annual mean precipitation (a) and deviations of MH, LGM, and PLIO annual mean near-surface temperatures from PI values (b). Units are millimetres per year. 
regional climate. The cluster means of seasonal near-surface temperature amplitude and seasonal precipitation amplitude are referred to as temperature and precipitation amplitude. The median, 25 th percentile, 75 th percentile, minimum, and maximum values for annual mean precipitation are referred to as $P_{\mathrm{md}}, P_{25}, P_{75}, P_{\mathrm{min}}$, and $P_{\mathrm{max}}$, respectively. Likewise, the same statistics for temperature are referred to as $T_{\mathrm{md}}, T_{25}$, $T_{75}, T_{\min }$, and $T_{\max }$. These are presented as box plots of climate variables in different time periods. When the character of a climate cluster is described as "high", "moderate", and "low", the climatic attribute's values are described relative to the value range of the specific region in time; thus high PLIO precipitation rates may be higher than high LGM precipitation rates. The character is presented in a raster plot to allow compact visual representation of it. The actual mean values for each variable in every time slice and region-specific cluster are included in tables in the Supplement.

\subsubsection{Climate change and palaeoclimate characterisation in South, central, and East Asia}

This section describes the regional climatology of the four investigated Cenozoic time slices and how precipitation and temperature changes from PLIO to PI times in tropical, temperate, and high-altitude regions. LGM and PLIO simulations show the largest simulated temperature and precipitation deviations (Fig. 4b) from PI temperature and precipitation (Fig. 4a) in the South Asia region. LGM temperatures are $1-7^{\circ} \mathrm{C}$ below PI temperatures and the direction of deviation is uniform across the study region. PLIO temperature is mostly above PI temperatures by $1-7^{\circ} \mathrm{C}$. The cooling of $3-$ $5^{\circ} \mathrm{C}$ in the region immediately south of the Himalayan orogen represents one of the few exceptions. Deviations of $\mathrm{MH}$ precipitation from PI precipitation in the region are greatest along the eastern Himalayan orogeny, which experiences an increase in precipitation $\left(\leq 2000 \mathrm{~mm} \mathrm{a}^{-1}\right)$. The same region experiences a notable decrease in precipitation in the LGM simulation, which is consistent in direction with the prevailing precipitation trend on land during the LGM. PLIO precipitation on land is typically higher than PI precipitation.

Annual means of precipitation and temperature spatially averaged for the regional subdivisions and the different time slice simulations have been compared. The value range $P_{25}$ to $P_{75}$ of precipitation is higher for tropical South Asia than for temperate and high-altitude South Asia (Fig. 5a-c). The LGM values for $P_{25}, P_{\mathrm{md}}$, and $P_{75}$ are lower than for the other time slice simulations, most visibly for tropical South Asia (ca. $100 \mathrm{~mm} \mathrm{a}^{-1}$ ). The temperature range (both $T_{75}-$ $T_{25}$ and $\left.T_{\max }-T_{\min }\right)$ is smallest in hot (ca. $21^{\circ} \mathrm{C}$ ) tropical South Asia, wider in high-altitude (ca. $-8^{\circ} \mathrm{C}$ ) South Asia, and widest in temperate (ca. $2^{\circ} \mathrm{C}$ ) South Asia (Fig. 5d-f). $T_{\mathrm{md}}, T_{25}$, and $T_{75}$ values for the LGM are ca. $1^{\circ} \mathrm{C}, 1-2$, and $2{ }^{\circ} \mathrm{C}$ below PI and MH temperatures in tropical, temperate, and high-altitude South Asia, respectively, whereas the same temperature statistics for the PLIO simulation are ca. $1^{\circ} \mathrm{C}$ above PI and MH values in all regional subdivisions (Fig. 5df). With respect to PI and MH values, precipitation and temperature are generally lower in the LGM and higher in the PLIO in tropical, temperate, and high-altitude South Asia.

In all time periods, the wettest climate cluster $C_{1}$ covers an area along the southeastern Himalayan orogen (Fig. 6a-d) and is defined by the highest precipitation amplitude (dark blue, Fig. 6e-h). $\mathrm{C}_{5(\mathrm{PI})}, \mathrm{C}_{3(\mathrm{MH})}, \mathrm{C}_{4(\mathrm{LGM})}$, and $\mathrm{C}_{5(\mathrm{PLIO})}$ are characterised by (dark blue, Fig. 6e-h) the highest temperatures and $u$-wind and $v$-wind speeds during the summer monsoon in their respective time periods, whereas $\mathrm{C}_{4(\mathrm{PI})}, \mathrm{C}_{5(\mathrm{MH})}$, and $\mathrm{C}_{6(\mathrm{LGM})}$ are defined by low temperatures and the highest temperature amplitude and $u$-wind and $v$-wind speeds outside the monsoon season (in January) in their respective time periods (Fig. 6e-h). The latter three climate classes cover much of the more continental, northern landmass in their respective time periods and represent a cooler climate affected more by seasonal temperature fluctuations (Fig. 6a-d). The two wettest climate clusters $C_{1}$ and $C_{2}$ are more restricted to the eastern end of the Himalayan orogen in the LGM than during other times, indicating that the LGM precipitation distribution over the South Asia landmass is more concentrated in this region than in other time slice experiments.

\subsubsection{Climate change and palaeoclimate characterisation in the Andes, western South America}

This section describes the cluster-analysis-based regional climatology of the four investigated late Cenozoic time slices and illustrates how precipitation and temperature changes from PLIO to PI in tropical and temperate low- and highaltitude (i.e. Andes) regions in western South America (Figs. 7-9).

LGM and PLIO simulations show the largest simulated deviations (Fig. 7b) from PI temperature and precipitation (Fig. 7a) in western South America. The direction of LGM temperature deviations from PI temperatures is negative and uniform across the region. LGM temperatures are typically $1-3^{\circ} \mathrm{C}$ below PI temperatures across the region and $1-7^{\circ} \mathrm{C}$ below PI values in the Peruvian Andes, which also experience the strongest and most widespread increase in precipitation during the LGM $\left(\leq 1800 \mathrm{~mm} \mathrm{a}^{-1}\right)$. Other regions, such as much of the northern Andes and tropical South America, experience a decrease in precipitation in the same experiment. PLIO temperature is mostly elevated above PI temperatures by $1-5^{\circ} \mathrm{C}$. The Peruvian Andes experience a decrease in precipitation $(\leq 2600 \mathrm{~mm})$, while the northern Andes are wetter in the PLIO simulation compared to the PI control simulation.

PI, MH, LGM, and PLIO precipitation and temperature means for regional subdivisions have been compared. The $P_{25}$ to $P_{75}$ range is smallest for the relatively dry temperate Andes and largest for tropical South America and the tropical Andes (Fig. 8a-d). $P_{\max }$ is lowest in the PLIO in all 

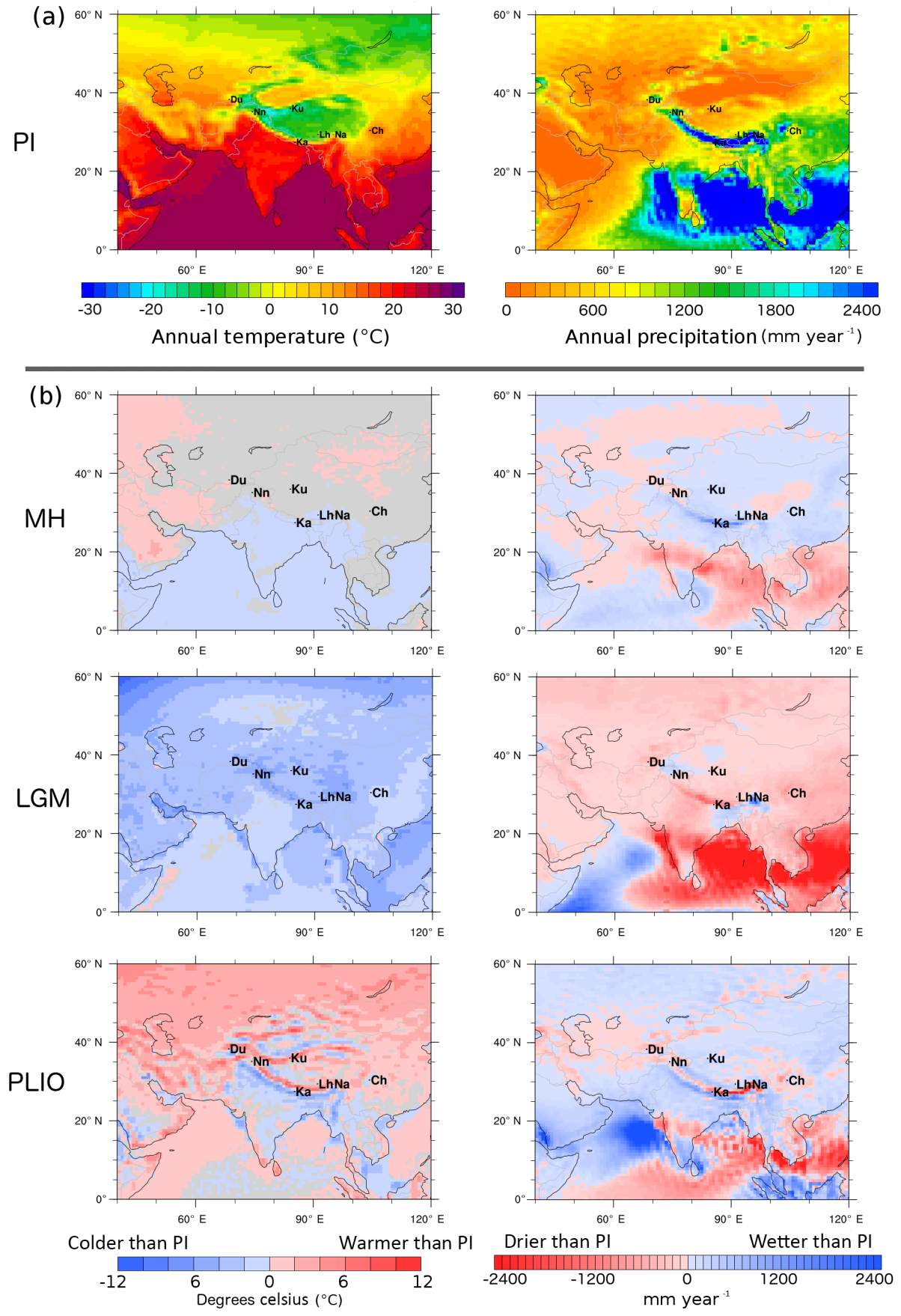

Figure 4. PI annual mean near-surface temperatures (a) and deviations of MH, LGM, and PLIO annual mean near-surface temperatures from PI values (b) for the South Asia region. Insignificant $(p<99 \%)$ differences (as determined by a $t$ test) are greyed out.

four regional subdivisions even though $P_{\mathrm{md}}, P_{25}$, and $P_{75}$ in the PLIO simulation are similar to the same statistics calculated for PI and MH time slices. $P_{\mathrm{md}}, P_{25}$, and $P_{75}$ for the LGM are ca. $50 \mathrm{~mm} \mathrm{a}^{-1}$ lower in tropical South America and ca. $50 \mathrm{~mm} \mathrm{a}^{-1}$ higher in the temperate Andes. Average PLIO temperatures are slightly warmer and LGM temperatures are slightly colder than PI and MH temperatures in tropical and temperate South America (Fig. 8e and f). These differences are more pronounced in the Andes, however. $T_{\mathrm{md}}, T_{25}$, and $T_{75}$ are ca. $5^{\circ} \mathrm{C}$ higher in the PLIO climate than in PI and $\mathrm{MH}$ climates in both the temperate and tropical Andes, whereas 

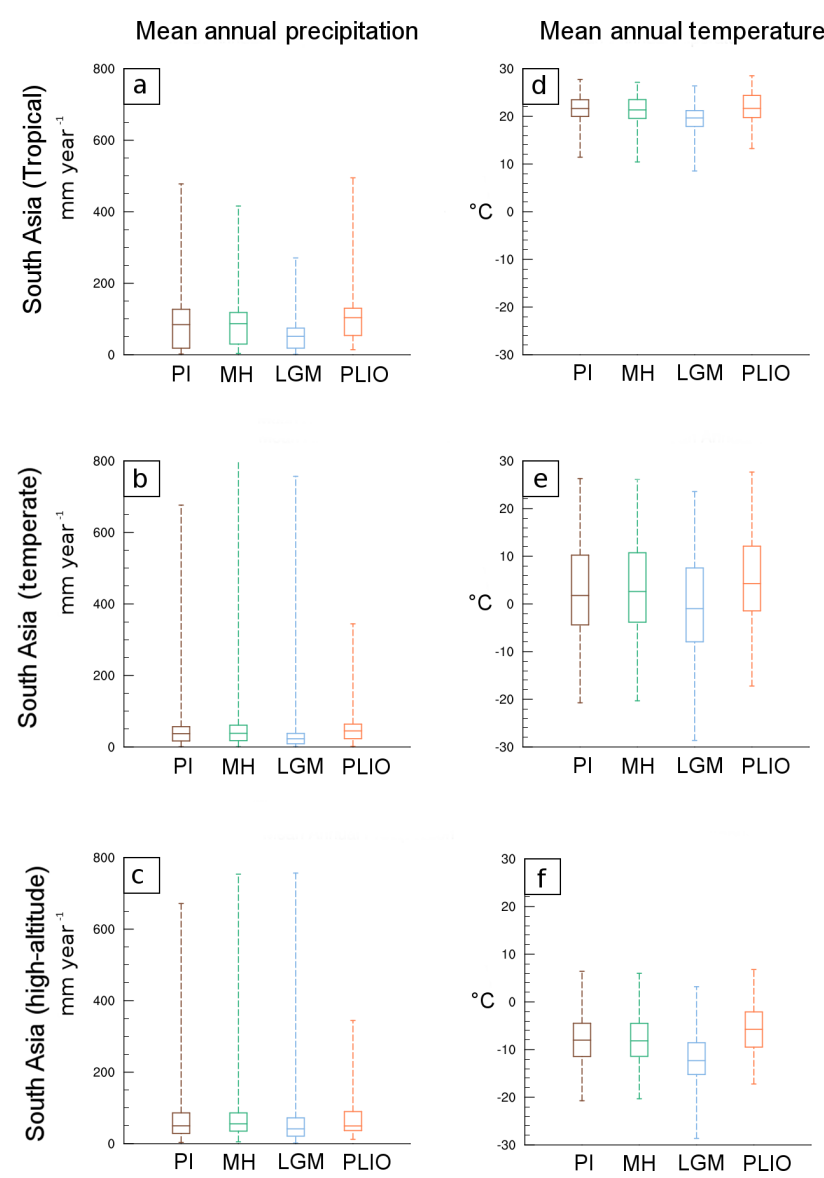

Figure 5. PI, MH, LGM, and PLIO annual mean precipitation in (a) tropical South Asia, (b) temperate South Asia, and (c) high-altitude South Asia; PI, MH, LGM, and PLIO annual mean temperatures in (d) tropical South Asia, (e) temperate South Asia, and (f) highaltitude South Asia. For each time slice, the minimum, lower 25th percentile, median, upper 75 th percentile, and maximum are plotted.

the same temperatures for the LGM are ca. $2-4{ }^{\circ} \mathrm{C}$ below PI and $\mathrm{MH}$ values (Fig. 8g and h).

For the LGM, the model computes drier-than-PI conditions in tropical South America and the tropical Andes, enhanced precipitation in the temperate Andes, and a decrease in temperature that is most pronounced in the Andes. For the PLIO, the model predicts precipitation similar to PI, but with lower precipitation maxima. PLIO temperatures generally increase from PI temperatures, and this increase is most pronounced in the Andes.

The climate variability in the region is described by six different clusters (Fig. 9a-d), which have similar attributes in all time periods. The wettest climate $\mathrm{C}_{1}$ is also defined by moderate to high precipitation amplitudes, low temperatures, and moderate to high $u$-wind speeds in summer and winter in all time periods (dark blue, Fig. 9e-h). $\mathrm{C}_{2(\mathrm{PI})}, \mathrm{C}_{2(\mathrm{MH})}, \mathrm{C}_{3(\mathrm{LGM})}$, and $\mathrm{C}_{2 \text { (PLIO) }}$ are characterised by high temperatures and low seasonal temperature amplitude (dark blue, Fig. 9e-h), ge-

ographically cover the north of the investigated region, and represent a more tropical climate. $\mathrm{C}_{5(\mathrm{PI})}, \mathrm{C}_{5(\mathrm{MH})}, \mathrm{C}_{6(\mathrm{LGM})}$, and $\mathrm{C}_{6 \text { (PLIO) }}$ are defined by low precipitation and precipitation amplitude, high temperature amplitude, and high $u$-wind speeds in winter (Fig. 9e-h), cover the low-altitude south of the investigated region (Fig. 9a-d), and represent dry, extratropical climates with more pronounced seasonality. In the PLIO simulation, the lower-altitude east of the region has four distinct climates, whereas the analysis for the other time slice experiments only yield three distinct climates for the same region.

\subsubsection{Climate change and palaeoclimate characterisation in the St Elias Mountains, southeastern Alaska}

This section describes the changes in climate and the results from the cluster analysis for southern Alaska (Figs. 10-12). As is the case for the other study areas, LGM and PLIO simulations show the largest simulated deviations (Fig. 10b) from PI temperature and precipitation (Fig. 10a). The sign of LGM temperature deviations from PI temperatures is negative and uniform across the region. LGM temperatures are typically $1-9{ }^{\circ} \mathrm{C}$ below PI temperatures, with the east of the study area experiencing the largest cooling. PLIO temperatures are typically $1-5^{\circ} \mathrm{C}$ above PI temperatures and the warming is uniform for the region. In comparison to the PI simulation, LGM precipitation is lower on land but higher $(\leq 2300 \mathrm{~mm})$ in much of the coastal regions of southern Alaska. Annual PLIO precipitation is mostly higher $(\leq 800 \mathrm{~mm})$ than for PI.

$P_{\mathrm{md}}, P_{25}, P_{75}, P_{\min }$, and $P_{\max }$ for southern Alaskan mean annual precipitation do not differ much between PI, MH, and PLIO climates, while $P_{\mathrm{md}}, P_{25}, P_{75}$, and $P_{\min }$ decrease by ca. $20-40 \mathrm{~mm} \mathrm{a}^{-1}$ and $P_{\max }$ increases during the LGM (Fig. 11a). The Alaskan PLIO climate is distinguished from the PI and $\mathrm{MH}$ climates by its higher $\left(\mathrm{ca} .2^{\circ} \mathrm{C}\right.$ ) regional temperature means, $T_{25}, T_{75}$, and $T_{\mathrm{md}}$ (Fig. 11b). Mean annual temperatures, $T_{25}, T_{75}, T_{\min }$, and $T_{\max }$, are lower in the LGM than in any other considered time period (Fig. 11b), and about $3-5^{\circ} \mathrm{C}$ lower than during the PI and $\mathrm{MH}$.

Distinct climates are present in the PLIO to PI simulations for southeastern Alaska. Climate cluster $C_{1}$ is always geographically restricted to coastal southeastern Alaska (Fig. 12a-d) and characterised by the highest precipitation, precipitation amplitude, and temperature and by relatively low temperature amplitude (dark blue, Fig. 12e-h). Climate $\mathrm{C}_{2}$ is characterised by moderate to low precipitation, precipitation amplitude, and temperature and by low temperature amplitude. $\mathrm{C}_{2}$ is either restricted to coastal southeastern Alaska (in MH and LGM climates) or coastal southern Alaska (in PI and PLIO climates). Climate $\mathrm{C}_{3}$ is described by low precipitation, precipitation amplitude, and temperature and moderate temperature amplitude in all simulations. It covers coastal western Alaska and separates climate $\mathrm{C}_{1}$ and $\mathrm{C}_{2}$ from the northern $\mathrm{C}_{4}$ climate. Climate $\mathrm{C}_{4}$ is distin- 

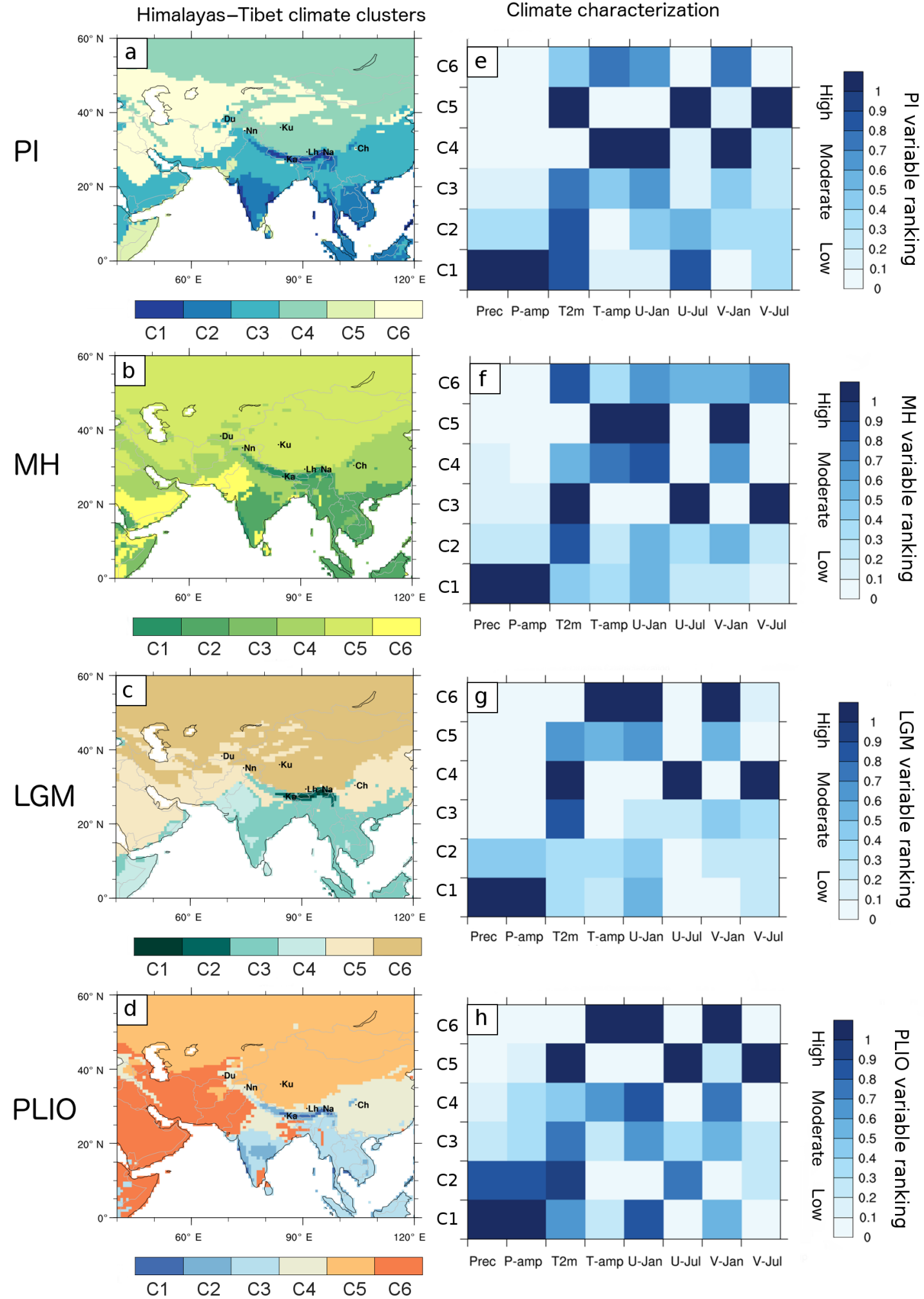

Figure 6. Geographical coverage and characterisation of climate classes $\mathrm{C}_{1}-\mathrm{C}_{6}$ based on cluster analysis of eight variables (near-surface temperature, seasonal near-surface temperature amplitude, total precipitation, seasonal precipitation amplitude, $u$ wind in January and July, $v$ wind in January and July) in the South Asia region. The geographical coverage of the climates $\mathrm{C}_{1}-\mathrm{C}_{6}$ is shown on the left for the PI (a), MH (b), LGM (c), and PLIO (d); the complementary, time-slice-specific characterisation of $\mathrm{C}_{1}-\mathrm{C}_{6}$ for the PI (e), MH (f), LGM (g), and PLIO (h) is shown on the right. 

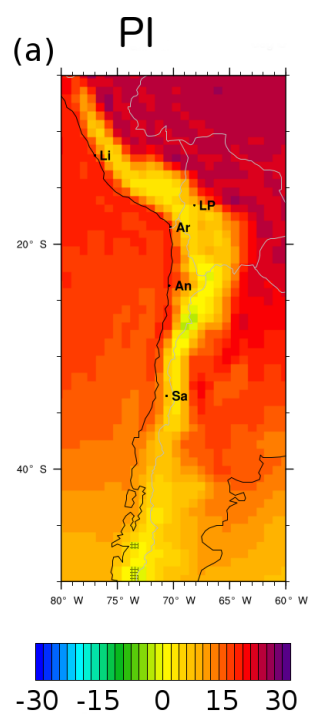

Annual temperature $\left({ }^{\circ} \mathrm{C}\right)$
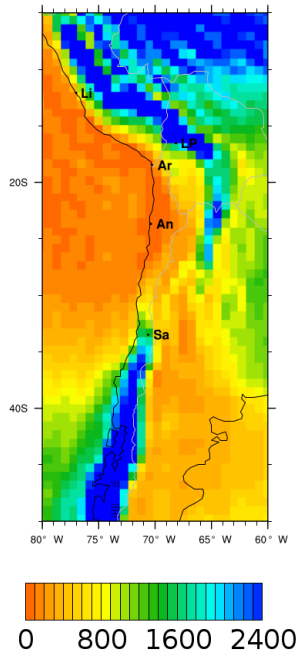

Annual precipitation $\left(\mathrm{mm}\right.$ year $\left.^{-1}\right)$
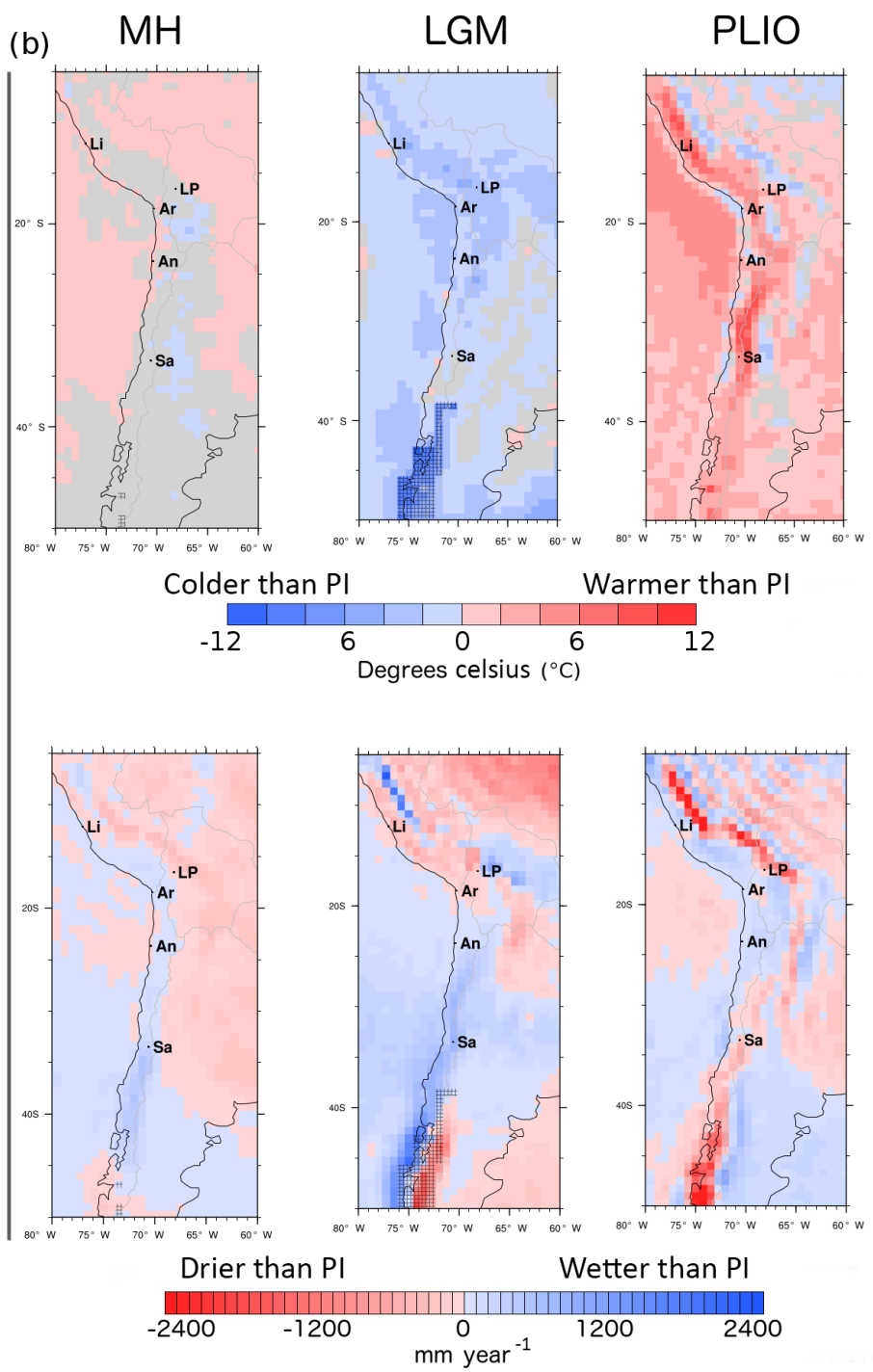

Ice cover

Figure 7. PI annual mean near-surface temperatures (a) and deviations of MH, LGM, and PLIO annual mean near-surface temperatures from PI values (b) for western South America. Insignificant $(p<99 \%)$ differences (as determined by a $t$ test) are greyed out.

guished by the highest mean temperature amplitude, by low temperature and precipitation amplitude, and by the lowest precipitation.

The geographical ranges of PI climates $\mathrm{C}_{1}-\mathrm{C}_{4}$ and PLIO climates $\mathrm{C}_{1}-\mathrm{C}_{4}$ are similar. $\mathrm{C}_{1 \text { (PI/PLIO) }}$ and $\mathrm{C}_{2 \text { (PI/PLIO) }}$

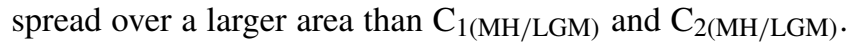
$\mathrm{C}_{2 \text { (PI/PLIO) }}$ are not restricted to coastal southeastern Alaska, but also cover the coastal southwest of Alaska. The main difference in characterisation between PI and PLIO climates $\mathrm{C}_{1}-\mathrm{C}_{4}$ lies in the greater difference (towards lower values) in precipitation, precipitation amplitude, and temperature from $\mathrm{C}_{1 \text { (PLIO) }}$ to $\mathrm{C}_{2 \text { (PLIO) }}$ compared to the relatively moderate decrease in those means from $\mathrm{C}_{1(\mathrm{PI})}$ to $\mathrm{C}_{2(\mathrm{PI})}$.

\subsubsection{Climate change and palaeoclimate characterisation in the Cascade Range, US Pacific Northwest}

This section describes the character of regional climatology in the US Pacific Northwest and its change over time (Figs. 13-15). The region experiences cooling of typically $9-11^{\circ} \mathrm{C}$ on land during the LGM and warming of $1-5^{\circ} \mathrm{C}$ during the PLIO (Fig. 13b) when compared to PI temperatures (Fig. 13a). LGM precipitation increases over water, decreases on land by $\leq 800 \mathrm{~mm} \mathrm{a}^{-1}$ in the north and in the vicinity of Seattle, and increases on land by $\leq 1400 \mathrm{~mm} \mathrm{a}^{-1}$ on Vancouver Island and around Portland and the Olympic Mountains. Conversely, PLIO precipitation does not deviate 

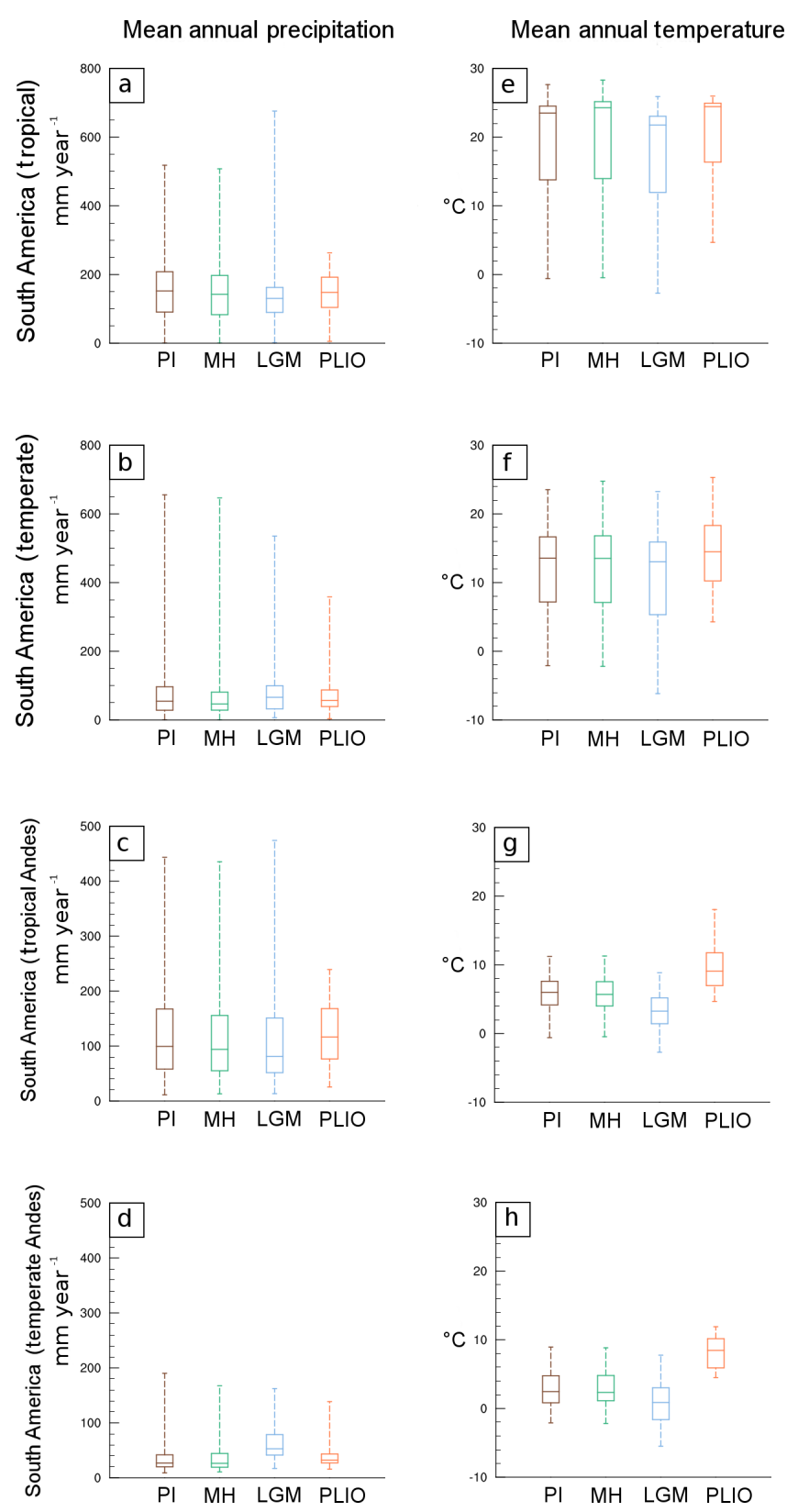

Figure 8. PI, MH, LGM, and PLIO annual mean precipitation in (a) tropical South America, (b) temperate South America, (c) the tropical Andes, and (d) the temperate Andes; PI, MH, LGM, and PLIO annual mean temperatures in (e) tropical South America, (f) temperate South America, (g) the tropical Andes, and (h) the temperate Andes. For each time slice, the minimum, lower 25th percentile, median, upper 75th percentile, and maximum are plotted.

much from PI values over water and varies in the direction of deviation on land. MH temperature and precipitation deviation from PI values is negligible.

$P_{\mathrm{md}}, P_{25}, P_{75}, P_{\min }$, and $P_{\max }$ for the Cascade Range do not notably differ between the four time periods (Fig. 14a). The LGM range of precipitation values is slightly larger than

that of the PI and MH with slightly increased $P_{\mathrm{md}}$, while the respective range is smaller for simulation of the PLIO. The $T_{\mathrm{md}}, T_{25}, T_{75}$, and $T_{\max }$ values for the PLIO climate are ca. $2{ }^{\circ} \mathrm{C}$ higher than those values for PI and MH (Fig. 14b). All temperature statistics for the LGM are notably (ca. $13^{\circ} \mathrm{C}$ ) below their analogues in the other time periods (Fig. 14b).

PI, LGM, and PLIO clusters are similar in both their geographical patterns (Fig. 15a, c, d) and their characterisation by mean values (Fig. 15e, g, h). $\mathrm{C}_{1}$ is the wettest cluster and shows the highest amplitude in precipitation. The common characteristics of the $\mathrm{C}_{2}$ cluster are moderate to high precipitation and precipitation amplitude. $\mathrm{C}_{4}$ is characterised by the lowest precipitation and precipitation amplitudes and the highest temperature amplitudes. Regions assigned to clusters $\mathrm{C}_{1}$ and $\mathrm{C}_{2}$ are in proximity to the coast, whereas $\mathrm{C}_{4}$ is geographically restricted to more continental settings.

In the PI and LGM climates, the wettest cluster $\mathrm{C}_{1}$ is also characterised by high temperatures (Fig. 10e, g). However, virtually no grid boxes were assigned to $\mathrm{C}_{1(\mathrm{LGM})}$. $\mathrm{C}_{1(\mathrm{MH})}$ differs from other climate states' $C_{1}$ clusters in that it is also described by moderate to high near-surface temperature and temperature amplitude (Fig. 10f), and in that it is geographically less restricted and covers much of Vancouver Island and the continental coastline north of it (Fig. 10b). Near-surface temperatures are highest for $\mathrm{C}_{2}$ in PI, LGM, and PLIO climates (Fig. 10e, g, h) and low for $\mathrm{C}_{2(\mathrm{MH})}$ (Fig. 10f). $\mathrm{C}_{2(\mathrm{MH})}$ is also geographically more restricted than $\mathrm{C}_{2}$ clusters in PI, LGM, and PLIO climates (Fig. 10a-d). $\mathrm{C}_{2(\mathrm{PI})}, \mathrm{C}_{2(\mathrm{MH})}$, and $\mathrm{C}_{2(\mathrm{LGM})}$ have a low temperature amplitude (Fig. 10e-g), whereas $\mathrm{C}_{2 \text { (PLIO) }}$ is characterised by a moderate temperature amplitude (Fig. 10h).

\section{Discussion}

In the following, we synthesise our results and compare to previous studies that investigate the effects of temperature and precipitation change on erosion. Since our results do not warrant merited discussion of subglacial processes without additional work that is beyond the scope of this study, we instead advise caution in interpreting the presented precipitation and temperature results in an erosional context in which the regions are covered with ice. For convenience, ice cover is indicated in Figs. 2, 3, 7, 10 and 13, and a summary of ice cover used as boundary conditions for the different time slice experiments is included in the Supplement. Where possible, we relate the magnitude of climate change predicted in each geographical study area with terrestrial proxy data. 

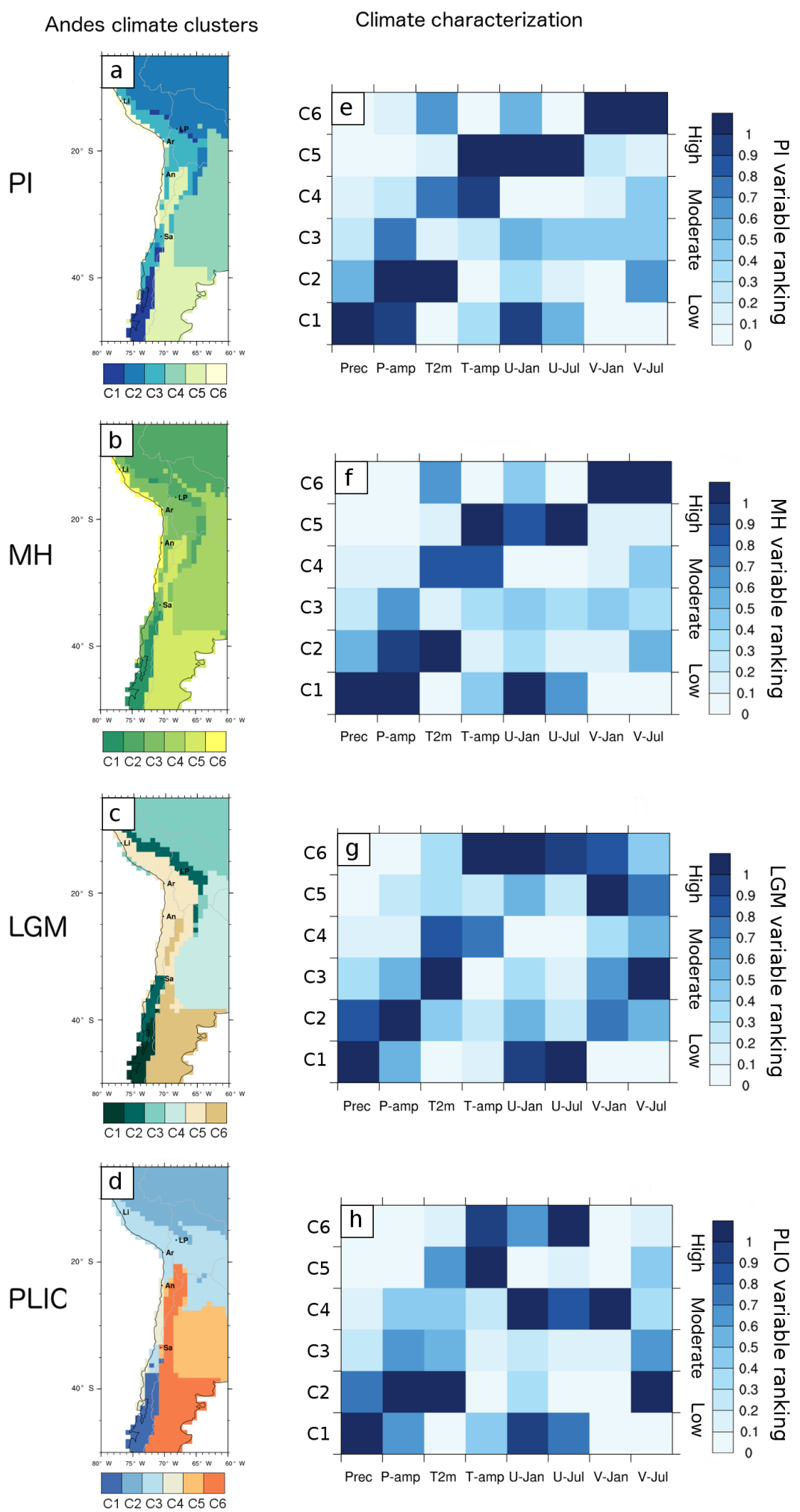

Figure 9. Geographical coverage and characterisation of climate classes $\mathrm{C}_{1}-\mathrm{C}_{6}$ based on cluster analysis of eight variables (near-surface temperature, seasonal near-surface temperature amplitude, precipitation, seasonal precipitation amplitude, $u$ wind in January and July, $v$ wind in January and July) in western South America. The geographical coverage of the climates $\mathrm{C}_{1}-\mathrm{C}_{6}$ is shown on the left for PI (a), MH (b), LGM (c), and PLIO (d); the complementary, time-slice-specific characterisation of $\mathrm{C}_{1}-\mathrm{C}_{6}$ for PI (e), MH (f), LGM (g), and PLIO (h) is shown on the right. 

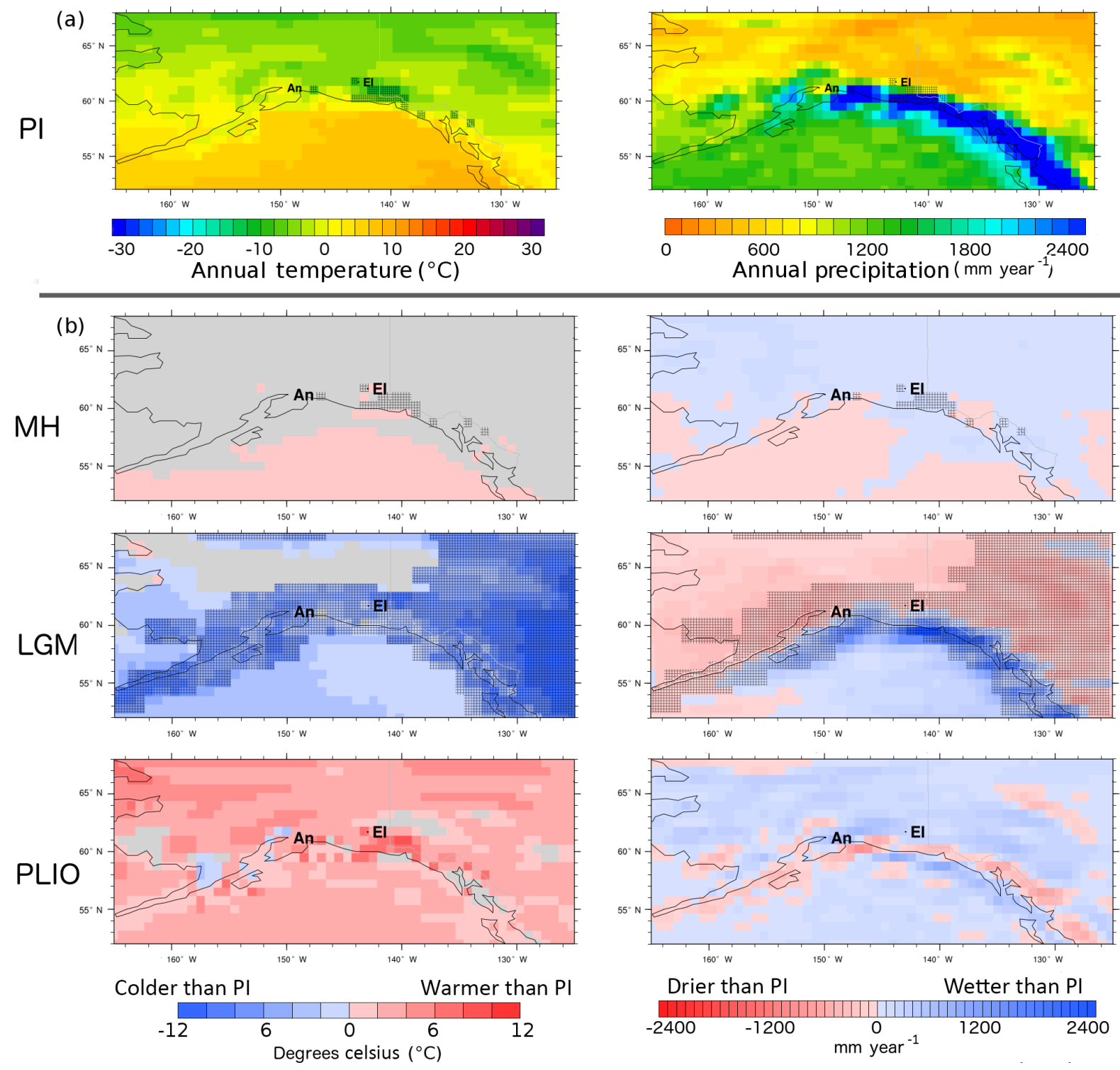

Ice cover

Figure 10. PI annual mean near-surface temperatures (a) and deviations of MH, LGM, and PLIO annual mean near-surface temperatures from PI values (b) for the southern Alaska region. Insignificant $(p<99 \%)$ differences (as determined by a $t$ test) are greyed out.

\subsection{Synthesis of temperature changes}

\subsubsection{Temperature changes and implications for weathering and erosion}

Changes in temperature can affect physical weathering due to temperature-induced changes in periglacial processes and promote frost cracking, frost creep (e.g. Matsuoka, 2001; Schaller et al., 2002; Matsuoka and Murton, 2008; Delunel et al., 2010; Andersen et al., 2015; Marshall et al., 2015), and biotic weathering and erosion (e.g. Moulton and Berner, 1998; Banfield et al., 1999; Dietrich and Perron, 2006).
Quantifying and understanding past changes in temperature is thus vital for our understanding of denudation histories. In the following, we highlight regions in the world where future observational studies might be able to document significant warming or cooling that would influence temperature-related changes in physical and chemical weathering over the last $\sim 3 \mathrm{Myr}$.

Simulated MH temperatures show little deviation (typically $<1^{\circ} \mathrm{C}$ ) from PI temperatures in the investigated regions (Fig. 2b), suggesting little difference in $\mathrm{MH}$ temperaturerelated weathering. The LGM experiences widespread cool- 

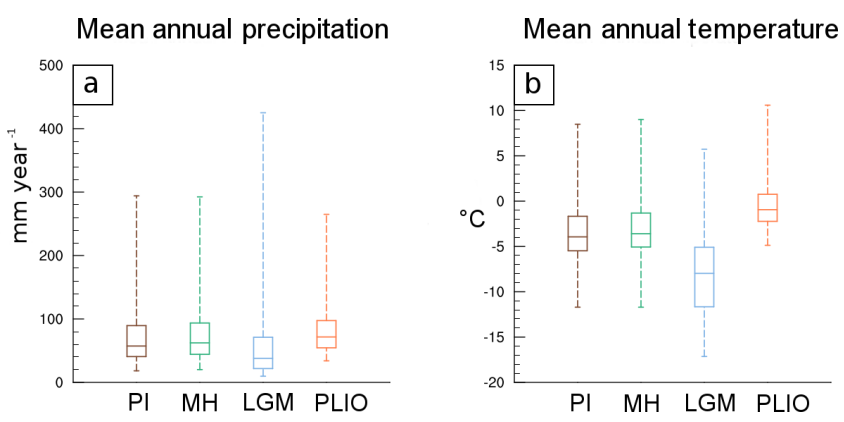

Figure 11. PI, MH, LGM, and PLIO annual mean precipitation (a) and mean annual temperatures (b) in southern Alaska. For each time slice, the minimum, lower 25 th percentile, median, upper 75 th percentile, and maximum are plotted.

ing, which is accentuated at the poles, increasing the Equatorto-pole pressure gradient and consequently strengthening global atmospheric circulation. Despite this global trend, cooling in coastal southern Alaska is higher $\left(\leq 9^{\circ} \mathrm{C}\right)$ than in central Alaska $\left(0 \pm 1{ }^{\circ} \mathrm{C}\right)$. The larger temperature difference in southern Alaska geographically coincides with ice cover (Fig. 10b) and should thus be interpreted in the context of a different erosional regime. Cooling in most of the lowerlatitude regions in South America and central to South East Asia is relatively mild. The greatest temperature differences in South America are observed for western Patagonia, which was mostly covered by glaciers. The Tibetan Plateau experiences more cooling $\left(3-5^{\circ} \mathrm{C}\right)$ than adjacent low-altitude regions $\left(1-3{ }^{\circ} \mathrm{C}\right)$ during the LGM.

The PLIO simulation is generally warmer, and temperature differences accentuate warming at the poles. Warming in simulation PLIO is greatest in parts of Canada, Greenland, and Antarctica (up to $19^{\circ} \mathrm{C}$ ), which geographically coincides with the presence of ice in the PI reference simulation and thus may be attributed to differences in ice cover. It should therefore also be regarded as areas in which process domain shifted from glacial to non-glacial. The warming in simulation PLIO in southern Alaska and the US Pacific Northwest is mostly uniform and in the range of $1-5^{\circ} \mathrm{C}$. As before, changes in ice cover reveal that the greatest warming may be associated with the absence of glaciers relative to the PI simulation. Warming in South America is concentrated at the Pacific west coast and the Andes between Lima and Chiclayo and along the Chilean-Argentinian Andes south of Bolivia $\left(\leq 9^{\circ} \mathrm{C}\right)$.

Overall, annual mean temperatures in the $\mathrm{MH}$ simulation show little deviation from PI values. The more significant temperature deviations of the colder LGM and of the warmer PLIO simulations are accentuated at the poles, leading to higher and lower Equator-to-pole temperature gradients, respectively. The largest temperature-related changes (relative to PI conditions) in weathering and subsequent erosion, in many cases through a shift in the process domain from glacial to non-glacial or vice versa, are therefore to be expected in the LGM and PLIO climates.

\subsubsection{Temperature comparison to other studies}

LGM cooling is accentuated at the poles, thus increasing the Equator-to-pole pressure gradient and consequently strengthens global atmospheric circulation, and is in general agreement with studies such as Otto-Bliesner et al. (2006) and Braconnot et al. (2007). The PLIO simulation shows little to no warming in the tropics and accentuated warming at the poles, as do findings of Salzmann et al. (2011), Robinson (2009), and Ballantyne (2010), respectively. This would reduce the Equator-to-pole sea and land surface temperature gradient, as also reported by Dowsett et al. (2010), and also weaken global atmospheric circulation. Agreement with proxy-based reconstructions, as is the case of the relatively little warming in lower latitudes, is not surprising given that SST reconstructions (derived from previous coarse resolution coupled ocean-atmosphere models) are prescribed in this uncoupled atmosphere simulation. It should be noted that coupled ocean-atmosphere simulations do predict more low-latitude warming (e.g. Stepanek and Lohmann, 2012; R. Zhang et al., 2013). The PLIO warming in parts of Canada and Greenland (up to $19^{\circ} \mathrm{C}$ ) is consistent with values based on multiproxy studies (Ballantyne et al., 2010). Due to a scarcity of palaeobotanical proxies in Antarctica, reconstruction-based temperature and ice sheet extent estimates for a PLIO climate have high uncertainties (Salzmann et al., 2011), making model validation difficult. Furthermore, controversy about relatively little warming in the south polar regions compared to the north polar regions remains (e.g. Hillenbrand and Fütterer, 2002; Wilson et al., 2002). Mid-latitude PLIO warming is mostly in the $1-3{ }^{\circ} \mathrm{C}$ range with notable exceptions of cooling in the northern tropics of Africa and on the Indian subcontinent, especially south of the Himalayan orogen.

\subsection{Synthesis of precipitation changes}

\subsubsection{Precipitation and implications for weathering and erosion}

Changes in precipitation affects erosion through river incision, sediment transport, and erosion due to extreme precipitation events and storms (e.g. Whipple and Tucker, 1999; Hobley et al., 2010). Furthermore, vegetation type and cover also co-evolve with variations in precipitation and with changes in geomorphology (e.g. Marston, 2010; Roering et al., 2010). These vegetation changes in turn modify hillslope erosion by increasing root mass and canopy cover and decreasing water-induced erosion via surface run-off (e.g. Gyssels et al., 2005). Therefore, understanding and quantifying changes in precipitation in different palaeoclimates is necessary for a more complete reconstruction of orogen denudation histories. A synthesis of predicted precipitation changes is provided below and highlights regions where changes in 

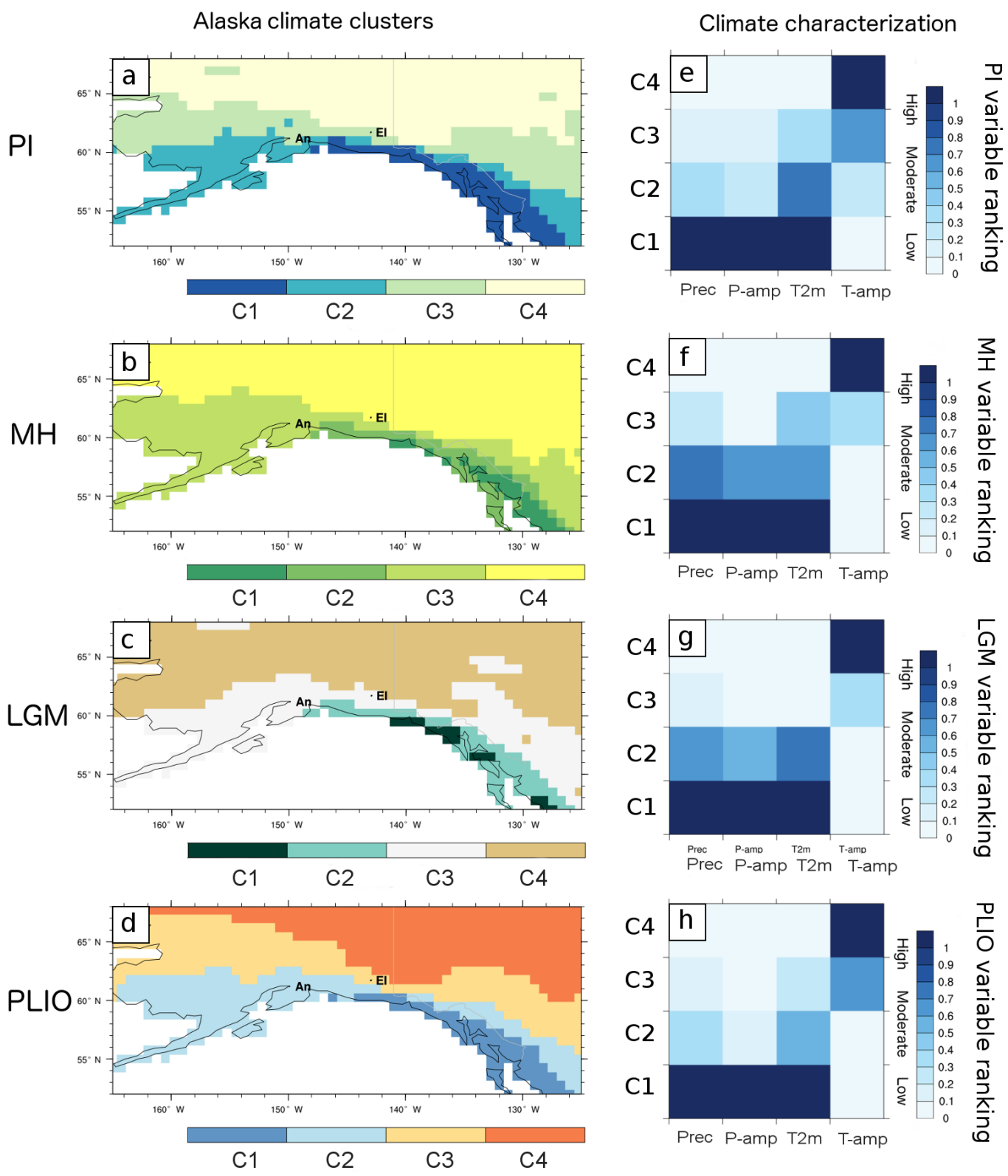

Figure 12. Geographical coverage of climate classes $C_{1}-C_{4}$ based on cluster analysis of four variables (near-surface temperature, seasonal near-surface temperature amplitude, total precipitation, seasonal total precipitation amplitude) in southern Alaska. The geographical coverage of the climates $\mathrm{C}_{1}-\mathrm{C}_{4}$ is shown on the left for PI (a), MH (b), LGM (c), and PLIO (d); the complementary, time-slice-specific characterisation of $\mathrm{C}_{1}-\mathrm{C}_{6}$ for PI (e), MH (f), LGM (g), and PLIO (h) is shown on the right.

river discharge and hillslope processes might be impacted by climate change over the last $\sim 3 \mathrm{Myr}$.

Most of North Africa is notably wetter during the $\mathrm{MH}$, which is characteristic of the African Humid Period (Sarnthein, 1978). This pluvial regional expression of the Holocene Climatic Optimum is attributed to sudden changes in the strength of the African monsoon caused by orbitalinduced changes in summer insolation (e.g. deMenocal et al., 2000). Southern Africa is characterised by a wetter climate to the east and drier climate to the west of the approximate lo- cation of the Congo Air Boundary (CAB), the migration of which has previously been cited as a cause for precipitation changes in East Africa (e.g. Juninger et al., 2014). In contrast, simulated MH precipitation rates show little deviation from the PI in most of the investigated regions, suggesting little difference in $\mathrm{MH}$ precipitation-related erosion. The $\mathrm{Hi}-$ malayan orogen is an exception and shows a precipitation increase of up to $2000 \mathrm{~mm} \mathrm{a}^{-1}$. The climate's enhanced erosion potential, which could result from such a climatic change, should be taken into consideration when palaeoerosion rates 

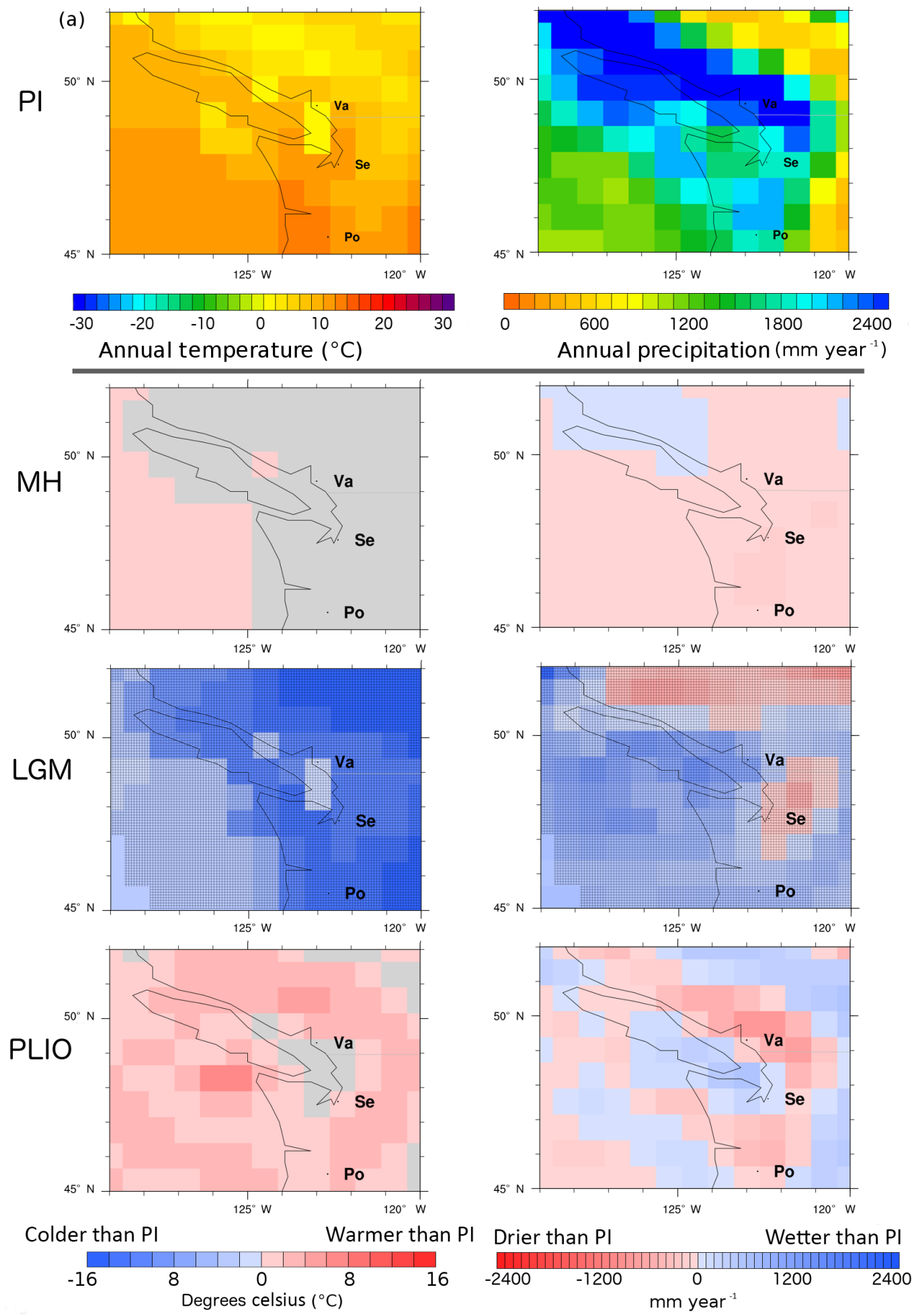

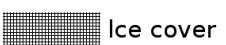

Figure 13. PI annual mean near-surface temperatures (a) and deviations of MH, LGM, and PLIO annual mean near-surface temperatures from PI values (b) for the US Pacific Northwest. Insignificant $(p<99 \%)$ differences (as determined by a $t$ test) are greyed out. 

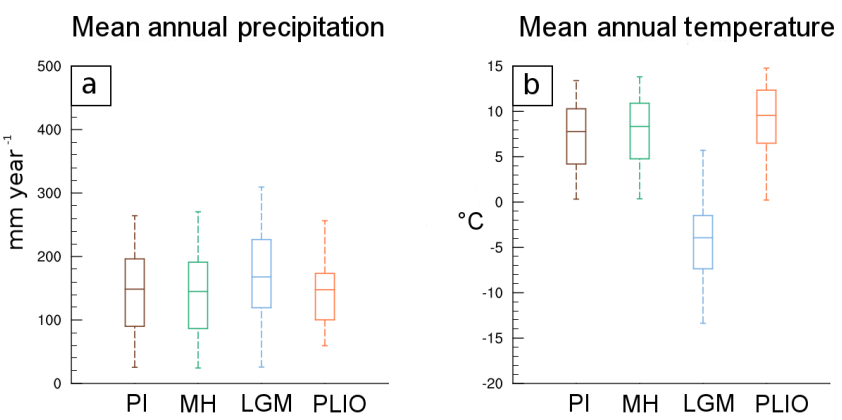

Figure 14. PI, MH, LGM, and PLIO annual mean precipitation (a) and annual mean temperatures (b) in the Cascades, US Pacific Northwest. For each time slice, the minimum, lower 25th percentile, median, upper 75 th percentile, and maximum are plotted.

estimated from the geological record in this area are interpreted (e.g. Bookhagen et al., 2005). Specifically, higher precipitation rates (along with differences in other rainfall-event parameters) could increase the probability of mass movement events on hillslopes, especially where hillslopes are close to the angle of failure (e.g. Montgomery, 2001), and modify fluxes to increase shear stresses exerted on river beds and increase stream capacity to enhance erosion on river beds (e.g. by abrasion).

Most precipitation on land is decreased during the LGM due to large-scale cooling and decreased evaporation over the tropics, resulting in an overall decrease in inland moisture transport (e.g. Braconnot et al., 2007). North America, south of the continental ice sheets, is an exception and experiences increases in precipitation. For example, the investigated US Pacific Northwest and the southeastern coast of Alaska experience strongly enhanced precipitation of $\leq 1700$ and $\leq 2300 \mathrm{~mm} \mathrm{a}^{-1}$, respectively. These changes geographically coincide with differences in ice extent. An increase in precipitation in these regions may have had direct consequences on the glaciers' mass balance and equilibrium line altitudes, where the glaciers' effectiveness in erosion is highest (e.g. Egholm et al., 2009; Yanites and Ehlers, 2012). The differences in the direction of precipitation changes, and accompanying changes in ice cover would likely result in more regionally differentiated variations in precipitationspecific erosional processes in the St Elias Mountains rather than causing systematic offsets for the LGM. Although precipitation is significantly reduced along much of the Himalayan orogen $\left(\leq 1600 \mathrm{~mm} \mathrm{a}^{-1}\right)$, northeastern India experiences strongly enhanced precipitation $\left(\leq 1900 \mathrm{~mm} \mathrm{a}^{-1}\right)$. This could have large implications for studies of uplift and erosion at orogen syntaxes, where highly localised and extreme denudation has been documented (e.g. Koons et al., 2013; Bendick and Ehlers, 2014).

Overall, the PLIO climate is wetter than the PI climate, in particular in the (northern) mid-latitudes and is possibly related to a northward shift of the northern Hadley cell boundary that is ultimately the result of a reduced Equatorto-pole temperature gradient (e.g. Haywood et al., 2000, 2013; Dowsett et al., 2010). Most of the PLIO precipitation over land increases, especially at the Himalayan orogen by $\leq 1400 \mathrm{~mm} \mathrm{a}^{-1}$, and decreases from eastern Nepal to Namcha Barwa $\left(\leq 2500 \mathrm{~mm} \mathrm{a}^{-1}\right)$. Most of the Atacama Desert experiences an increase in precipitation by $100-200 \mathrm{~mm} \mathrm{a}^{-1}$, which may have to be considered in erosion and uplift history reconstructions for the Andes. A significant increase $\left(\sim 2000 \mathrm{~mm} \mathrm{a}^{-1}\right)$ in precipitation from simulation PLIO to modern conditions is simulated for the eastern margin of the Andean Plateau in Peru and for northern Bolivia. This is consistent with recent findings of a pulse of canyon incision in these locations in the last $\sim 3$ Myr (Lease and Ehlers, 2013).

Overall, the simulated $\mathrm{MH}$ precipitation varies least from PI precipitation. The LGM is generally drier than the PI simulation, even though pockets of a wetter-than-PI climate do exist, such as much of coastal North America. Extratropical increased precipitation of the PLIO simulation and decreased precipitation of the LGM climate may be the result of decreased and increased Equator-to-pole temperature gradients, respectively.

\subsubsection{Precipitation comparison to other studies}

The large-scale LGM precipitation decrease on land, related to cooling and decreased evaporation over the tropics, and greatly reduced precipitation along much of the Himalayan orogeny, is consistent with previous studies by, for example, Braconnot et al. (2007). The large-scale PLIO precipitation increase due to a reduced Equator-to-pole temperature gradient has previously been pointed out by Haywood et al. (2000, 2013) and Dowsett et al. (2010), for example. A reduction of this gradient by ca. $5^{\circ} \mathrm{C}$ is indeed present in the PLIO simulation of this study (Fig. 2b). This precipitation increase over land agrees well with simulations performed at a lower spatial model resolution (see Stepanek and Lohmann, 2012). Section 4.4 includes a more in-depth discussion of how simulated MH and LGM precipitation differences compare with proxy-based reconstructions in South Asia and South America.

\subsection{Trends in late Cenozoic changes in regional climatology}

This section describes the major changes in regional climatology and highlights their possible implications on erosion rates.

\subsubsection{Himalayas-Tibet, South Asia}

In South Asia, cluster-analysis-based categorisation and description of climates (Fig. 6) remains similar throughout time. However, the two wettest climates $\left(\mathrm{C}_{1}\right.$ and $\left.\mathrm{C}_{2}\right)$ are geographically more restricted to the eastern Himalayan oro- 
Cascades climate clusters
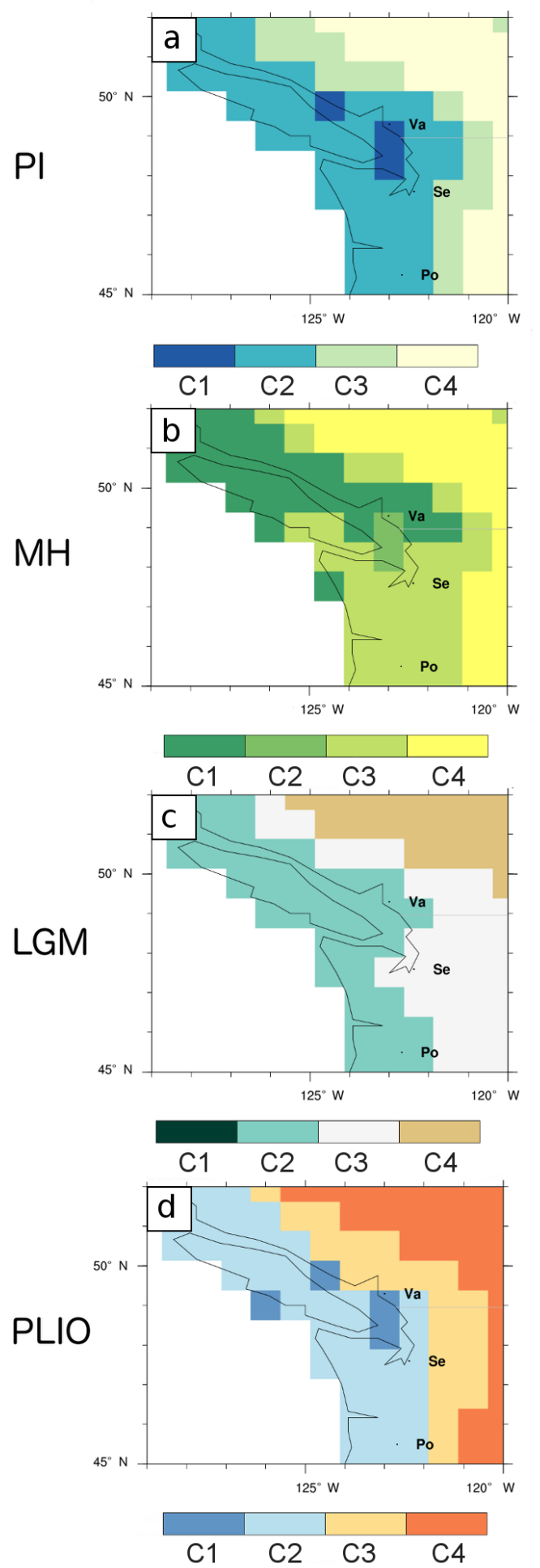

\section{Climate characterization}
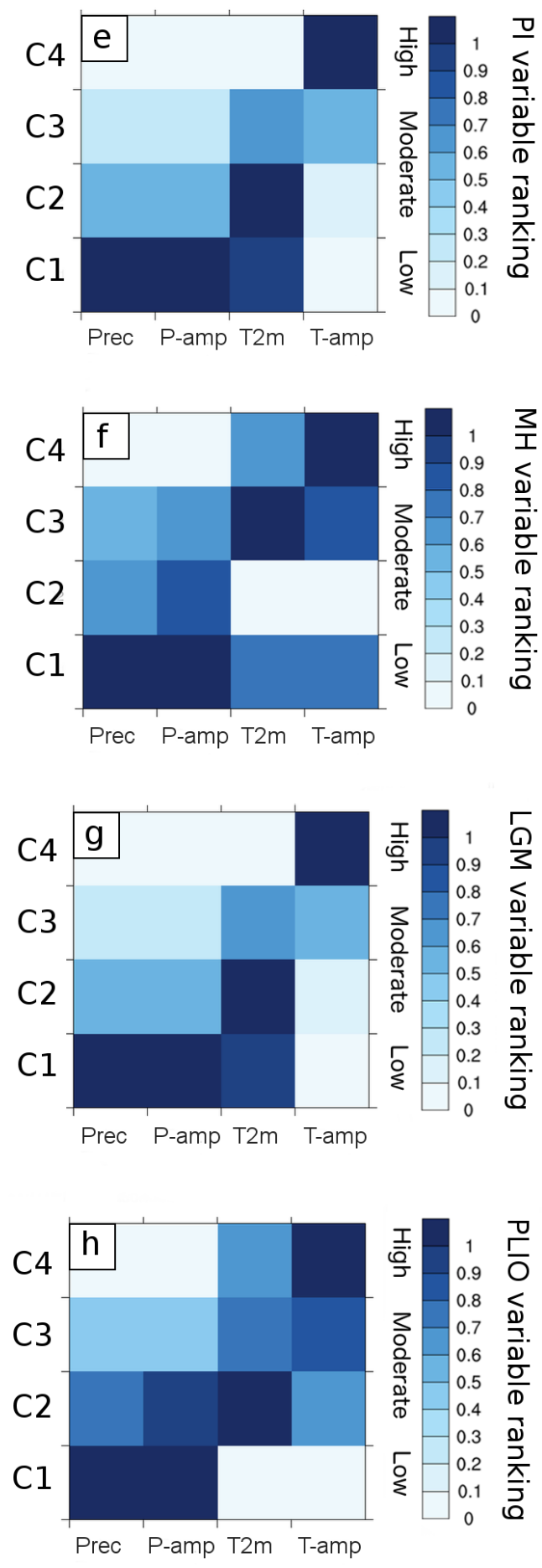

Figure 15. Geographical coverage and characterisation of climate classes $\mathrm{C}_{1}-\mathrm{C}_{4}$ based on cluster analysis of four variables (near-surface temperature, seasonal near-surface temperature amplitude, total precipitation, seasonal total precipitation amplitude) in the Cascades, US Pacific Northwest. The geographical coverage of the climates $\mathrm{C}_{1}-\mathrm{C}_{4}$ is shown on the left for PI (a), MH (b), LGM (c), and PLIO (d); the complementary, time-slice-specific characterisation of $\mathrm{C}_{1}-\mathrm{C}_{6}$ for PI (e), MH (f), LGM (g), and PLIO (h) is shown on the right. 
(a) $\mathrm{MH}$

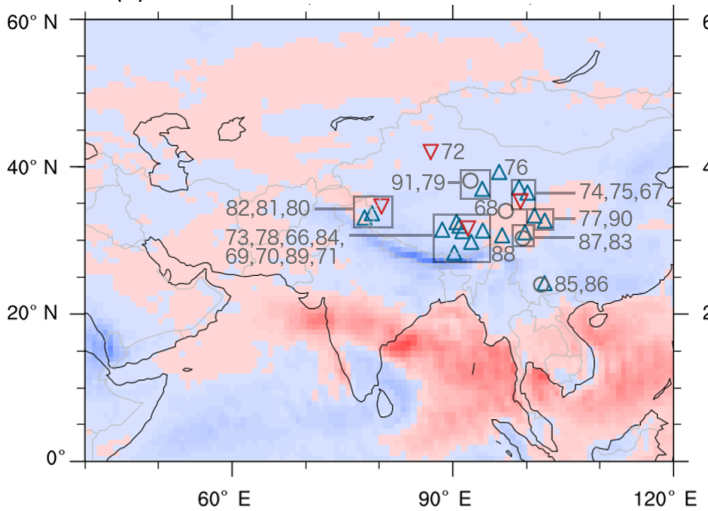

(b) LGM

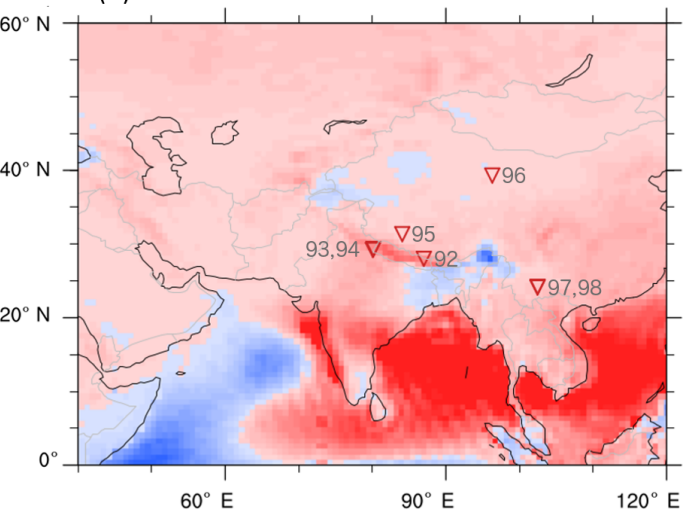

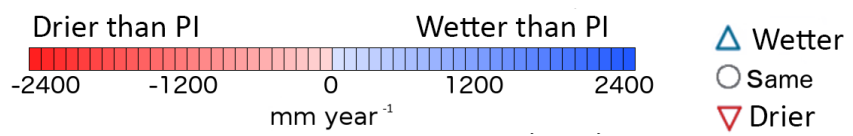

Figure 16. Simulated annual mean precipitation deviations of MH (a) and LGM (b) from PI values in South Asia, and temporally corresponding proxy-based reconstructions, indicating wetter (upward facing blue triangles), drier (downward facing red triangles), or similar (grey circles) conditions in comparison with modern climate. MH proxy-based precipitation differences are taken from Mügler et al. (2010) (66), Wischnewski et al. (2011) (67), Mischke et al. (2008), Wischnewski et al. (2011), Herzschuh et al. (2009) (68), Yanhong et al. (2006) (69), Morrill et al. (2006) (70), Wang et al. (2002) (71), Wuennemann et al. (2006) (72), Zhang et al. (2011), Morinaga et al. (1993), Kashiwaya et al. (1995) (73), Shen et al. (2005) (74), Liu et al. (2014) (75), Herzschuh et al. (2006a) (76), Zhang and Mischke (2009) (77), Nishimura et al. (2014) (78), Yu and Lai (2014) (79), Gasse et al. (1991) (80), Van Campo et al. (1996) (81), Demske et al. (2009) (82), Kramer et al. (2010) (83), Herzschuh et al. (2006b) (84), Hodell et al. (1999) (85), Hodell et al. (1999) (86), Shen et al. (2006) (87), Tang et al. (2000) (88), Tang et al. (2000) (89), Zhou et al. (2002) (90), Liu et al. (1998) (91), Asashi (2010) (92), Kotila et al. (2009) (93), Kotila et al. (2000) (94), Wang et al. (2002) (95), Hu et al. (2014) (96), Hodell et al. (1999) (97), and Hodell et al. (1999) (98).

gen in the LGM simulation. Even though precipitation over the South Asia region is generally lower, this shift indicates that rainfall on land is more concentrated in this region and that the westward drying gradient along the orogen is more accentuated than during other time periods investigated here. While there is limited confidence in the global atmospheric GCM's abilities to accurately represent mesoscale precipitation patterns (e.g. Cohen, 1990), the simulation warrants careful consideration of possible, geographically nonuniform offsets in precipitation in investigations of denudation and uplift histories.

MH precipitation and temperature in tropical, temperate, and high-altitude South Asia are similar to PI precipitation and temperature, whereas LGM precipitation and temperature are generally lower (by ca. $100 \mathrm{~mm} \mathrm{a}^{-1}$ and $1-2^{\circ} \mathrm{C}$, respectively), possibly reducing precipitation-driven erosion and enhancing frost-driven erosion in areas pushed into a near-zero temperature range during the LGM.

\subsubsection{Andes, South America}

Clusters in South America (Fig. 9), which are somewhat reminiscent of the Köppen and Geiger classification (Kraus, 2001), remain mostly the same over the last $3 \mathrm{Myr}$. In the PLIO simulation, the lower-altitude east of the region is characterised by four distinct climates, which suggests enhanced latitudinal variability in the PLIO climate compared to PI with respect to temperature and precipitation.

The largest temperature deviations from PI values are derived for the PLIO simulation in the (tropical and temperate) Andes, where temperatures exceed PI values by $5^{\circ} \mathrm{C}$. Conversely, LGM temperatures in the Andes are ca. $2-4^{\circ} \mathrm{C}$ below PI values in the same region (Fig. $7 \mathrm{~g}$ and $\mathrm{h}$ ). In the LGM simulation, tropical South America experiences ca. $50 \mathrm{~mm} \mathrm{a}^{-1}$ less precipitation; the temperate Andes receive ca. $50 \mathrm{~mm} \mathrm{a}^{-1}$ more precipitation than in PI and MH simulations. These latitude-specific differences in precipitation changes ought to be considered in attempts to reconstruct precipitation-specific palaeoerosion rates in the Andes on top of longitudinal climate gradients highlighted by Montgomery et al. (2001), for example.

\subsection{St Elias Mountains, southern Alaska}

Southern Alaska is subdivided into two wetter and warmer clusters in the south and two drier, colder clusters in the north. The latter are characterised by increased seasonal temperature variability due to being located at higher latitudes (Fig. 12). The different Equator-to-pole temperature gradients for LGM and PLIO may affect the intensity of the Pacific-North American teleconnection (PNA; Barnston and Livzey, 1987), which has significant influence on temper- 
(a) $\mathrm{MH}$

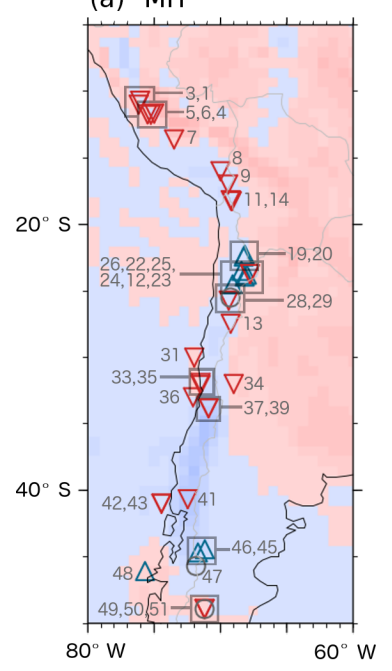

(b) LGM
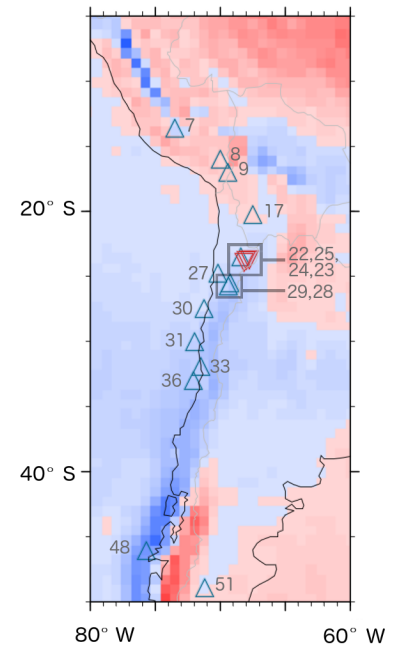

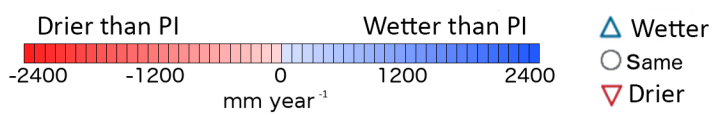

Figure 17. Simulated annual mean precipitation deviations of MH (a) and LGM (b) from PI values in South America and temporally corresponding proxy-based reconstructions, indicating wetter (upward-facing blue triangles), drier (downward-facing red triangles), or similar (grey circles) conditions in comparison with modern climate. MH proxy-based precipitation differences are taken from Bird et al. (2011) (1), Hansen et al. (1994) (2), Hansen et al. (1994) (3), Hansen et al. (1994) (4), Hansen et al. (1994) (5), Hansen et al. (1994) (6), Hillyer et al. (2009) (7), D'Agostino et al. (2002) (8), Baker et al. (2001) (9), Schwalb et al. (1999) (10), Schwalb et al. (1999) (11), Schwalb et al. (1999) (12), Schwalb et al. (1999) (13), Moreno et al. (2009) (14), Pueyo et al. (2011) (15), Mujica et al. (2015) (16), Fritz et al. (2004) (17), Gayo et al. (2012) (18), Latorre et al. (2006) (19), Latorre et al. (2003) (20), Quade et al. (2008) (21), Bobst et al. (2001) (22), Grosjean et al. (2001) (23), Betancourt et al. (2000) (24), Latorre et al. (2002) (25), Rech et al. (2003) (26), Diaz et al. (2012) (27), Maldonado et al. (2005) (28), Diaz et al. (2012) (29), Lamy et al. (2000) (30), Kaiser et al. (2008) (31), Maldonado et al. (2010) (32), Villagrán et al. (1990) (33), Méndez et al. (2015) (34), Maldonado and Villagrán (2006) (35), Lamy et al. (1999) (36), Jenny et al. (2002b) (37), Jenny et al. (2002b) (38), Villa-Martínez et al. (2003) (39), Bertrand et al. (2008) (40), De Basti et al. (2008) (41), Lamy et al. (2009) (42), Lamy et al. (2002) (43), Szeicz et al. (2003) (44), de Porras et al. (2012) (45), de Porras et al. (2014) (46), Markgraf et al. (2007) (47), Siani et al. (2010) (48), Gilli et al. (2001) (49), Markgraf et al. (2003) (50), and Stine and Stine (1990) (51).

atures and precipitation, especially in southeastern Alaska, and may in turn result in changes in regional precipitation and temperature patterns and thus on glacier mass balance. Changes in the Pacific Decadal Oscillation, which is related to the PNA pattern, has previously been connected to differences in late Holocene precipitation (Barron and Anderson, 2011). While this climate cluster pattern appears to be a robust feature for the considered climate states, and hence over the recent geologic history, the LGM sets itself apart from PI and MH climates by generally lower precipitation $(20-40 \mathrm{~mm})$ and lower temperatures $\left(3-5^{\circ} \mathrm{C}\right.$; Figs. 10,11$)$, which may favour frost-driven weathering during glacial climate states (e.g. Andersen et al., 2015; Marshall et al., 2015) in unglaciated areas, whereas glacial processes would have dominated most of this region as it was covered by ice. Simulation PLIO is distinguished by temperatures that exceed PI and $\mathrm{MH}$ conditions by ca. $2^{\circ} \mathrm{C}$ and by larger temperature and precipitation value ranges, possibly modifying temperatureand precipitation-dependent erosional processes in the region of southern Alaska.

\subsection{Cascade Range, US Pacific Northwest}

In all time slices, the geographic climate patterns, based on the cluster analysis (Fig. 15), represent an increase in the degree of continentality from the wetter coastal climates to the further inland climates with greater seasonal temperature amplitude and lower precipitation and precipitation amplitude (Fig. 15e-h). The most notable difference between the time slices is the strong cooling during the LGM, when temperatures are ca. $13{ }^{\circ} \mathrm{C}$ (Figs. 13, 14) below those of other time periods. Given that the entire investigated region was covered by ice (Fig. 13), we can assume a shift to glacially dominated processes.

\subsection{Comparison of simulated and observed precipitation differences}

The predicted precipitation differences reported in this study were compared with observed (proxy record) palaeoprecipitation change. Proxy-based precipitation reconstructions for the MH and LGM are presented for South Asia and South America for the purpose of assessing ECHAM5 model performance and for identifying inconsistencies among neighbouring proxy data. Due to the repeated glaciations, detailed terrestrial proxy records for the time slices investigated here are not available, to the best of our knowledge, for the Alaskan and Pacific NW USA studies. Although marine records and records of glacier extent are available in these regions, the results from them do not explicitly provide estimates of wetter-drier or colder-warmer conditions that can be spatially compared to the simulation estimates. For these two areas with no available records, the ECHAM5-predicted results therefore provide predictions from which future studies can formulate testable hypotheses to evaluate.

The palaeoclimate changes in terrestrial proxy records compiled here are reported as "wetter than today", "drier than today", or "the same as today" for each of the study locations and plotted on top of the simulation-based difference maps as upward-facing blue triangles, downward-facing red triangles, and grey circles, respectively (Figs. 16, 17). The numbers listed next to those indicators are the ID numbers 
assigned to the studies compiled for this comparison and are associated with a citation provided in the figure captions.

In South Asia, 14 out of 26 results from local studies agree with the model-predicted precipitation changes for the MH. The model seems able to reproduce the predominantly wetter conditions on much of the Tibetan Plateau, but predicts slightly drier conditions north of Chengdu, which is not reflected in local reconstructions. The modest mismatch between ECHAM5-predicted and proxy-based $\mathrm{MH}$ climate change in South Asia was also documented by Li et al. (2017), whose simulations were conducted at a coarser (T106) resolution. Despite these model-proxy differences, we note that there are significant discrepancies among the proxy data themselves in neighbouring locations in the $\mathrm{MH}$, highlighting caution in relying solely upon these data for regional palaeoclimate reconstructions. These differences could result from either poor age constraints on the reported values or systematic errors in the transfer functions used to convert proxy measurements to palaeoclimate conditions. The widespread drier conditions on the Tibetan Plateau and immediately north of Laos are confirmed by seven out of seven of the palaeoprecipitation reconstructions. Of the reconstructed precipitation changes, 23 out of 39 agree with model predictions for South America during the MH. The model-predicted wetter conditions in the central Atacama Desert, as well as the drier conditions northwest of Santiago are confirmed by most of the reconstructions. The wetter conditions in southernmost Peru and the border to Bolivia and Chile cannot be confirmed by local studies. Of the precipitation reconstructions, 11 out of 17 for the LGM are in agreement with model predictions. These include wetter conditions in most of Chile. The most notable disagreement can be seen in northeastern Chile at the border to Argentina and Bolivia, where model-predicted wetter conditions are not confirmed by reported reconstructions from local sites.

Model performance is, in general, higher for the LGM than for the $\mathrm{MH}$ and overall satisfactory given that it cannot be expected to resolve sub-grid-scale differences in reported palaeoprecipitation reconstructions. However, as mentioned above, it should be noted that some location ( $\mathrm{MH}$ of South Asia, and $\mathrm{MH}$ of norther Chile) discrepancies exist among neighbouring proxy samples and highlight the need for caution in how these data are interpreted. Other potential sources of error resulting in disagreement of simulated and proxybased precipitation estimates are the model's shortcomings in simulating orographic precipitation at higher resolutions, and uncertainties in palaeoclimate reconstructions at the local sites. In summary, although some differences are evident in both the model-proxy data comparison and among neighbouring proxy data themselves, the comparison above highlights an overall good agreement between the model and data for the South Asia and South American study areas. Thus, although future advances in GCM model parameterisations and new or improved palaeoclimate proxy techniques are likely, the palaeoclimate changes documented here are found to be in general robust and provide a useful framework for future studies investigating how these predicted changes in palaeoclimate impact denudation.

\section{Conclusions}

We present a statistical cluster-analysis-based description of the geographic coverage of possible distinct regional expressions of climates from four different time slices (Figs. 6, 9, $12,15)$. These are determined with respect to a selection of variables that characterise the climate of the region and may be relevant to weathering and erosional processes. While the geographic distribution of climate remains similar throughout time (as indicated by results of four different climate states representative for the climate of the last $3 \mathrm{Myr}$ ), results for the PLIO simulation suggests more climatic variability east of the Andes (with respect to near-surface temperature, seasonal temperature amplitude, precipitation, seasonal precipitation amplitude and seasonal $u$-wind and $v$ wind speeds). Furthermore, the wetter climates in the South Asia region retreat eastward along the Himalayan orogen for the LGM simulation; this is due to decreased precipitation along the western part of the orogen and enhanced precipitation on the eastern end, possibly signifying more localised high erosion rates.

Most global trends of the high-resolution LGM and PLIO simulations conducted here are in general agreement with previous studies (Otto-Bliesner et al., 2006; Braconnot et al., 2007; Wei and Lohmann, 2012; Lohmann et al., 2013; R. Zhang et al., 2013, 2014; Stepanek and Lohmann, 2012). The MH does not deviate notably from the PI, the LGM is relatively dry and cool, while the PLIO is comparably wet and warm. While the simulated regional changes in temperature and precipitation usually agree with the sign (or direction) of the simulated global changes, there are regionspecific differences in the magnitude and direction. For example, the LGM precipitation of the tropical Andes does not deviate significantly from PI precipitation, whereas LGM precipitation in the temperate Andes is enhanced.

Comparisons to local, proxy-based reconstructions of $\mathrm{MH}$ and LGM precipitation in South Asia and South America reveal satisfactory performance of the model in simulating the reported differences. The model performs better for the LGM than the $\mathrm{MH}$. We note however that compilations of proxy data such as we present here also identify inconsistences among neighbouring proxy data themselves, warranting caution in the extent to which both proxy data and palaeoclimate models are interpreted for MH climate change in South Asia and western South America.

The changes in regional climatology presented here are manifested, in part, by small to large magnitude changes in fluvial and hillslope relevant parameters such as precipitation and temperature. For the regions investigated here we find that precipitation differences among the PI, MH, LGM, 
and PLIO are in many areas around $\pm 200-600 \mathrm{~mm} \mathrm{yr}^{-1}$, and locally can reach maximums of $\pm 1000-2000 \mathrm{~mm} \mathrm{yr}^{-1}$ (Figs. 4, 7, 10, 13). In areas where significant precipitation increases are accompanied by changes in ice extent, such as parts of southern Alaska during the LGM, we would expect a shift in the erosional regime to glacier-dominated processes. Temperature differences between these same time periods are around $1-4^{\circ} \mathrm{C}$ in many places, but reach maximum values of $8-10^{\circ} \mathrm{C}$. Many of these maxima in the temperature differences geographically coincide with changes in ice sheet extent and must therefore be interpreted as part of a different erosional process domain. However, we also observe large temperature differences $\left(\sim 5^{\circ} \mathrm{C}\right)$ in unglaciated areas that would be affected by hillslope, frost cracking, and fluvial processes. The magnitude of these differences is not trivial, and will likely impact fluvial and hillslope erosion and sediment transport, as well as biotic and abiotic weathering. The regions of large-magnitude changes in precipitation and temperature documented here (Figs. 4, 7, 10, 13) offer the highest potential for future observational studies interested in quantifying the impact of climate change on denudation and weathering rates.

Data availability. The model simulations presented in this study are freely available to interested persons by contacting Sebastian G. Mutz or Todd A. Ehlers. We note however that the data files are very large $(\sim 4 \mathrm{~TB}$, and too large to archive in the Supplement) and require familiarity in reading or plotting NetCDF formatted files.

Supplement. The supplement related to this article is available online at: https://doi.org/10.5194/esurf-6-271-2018-supplement.

Competing interests. The authors declare that they have no conflict of interest.

Acknowledgements. European Research Council (ERC) Consolidator Grant number 615703 provided support for Sebastian G. Mutz. Additional support is acknowledged from the German science foundation (DFG) priority research program 1803 (EarthShape: Earth Surface Shaping by Biota; grants EH329/14-1 and EH329/17-1). We thank Byron Adams and Jessica Starke for constructive discussions. We also thank the reviewers (including Andrew Wickert) for their constructive feedback on this paper, which helped to significantly improve it. The DKRZ is thanked for computer time used for some of the simulations presented here. Christian Stepanek, Martin Werner, and Gerrit Lohmann acknowledge funding by the Helmholtz Climate Initiative Reklim and the Alfred Wegener Institute's research programme Marine, Coastal and Polar Systems.

Edited by: David Lundbek Egholm

Reviewed by: Andrew Wickert and one anonymous referee

\section{References}

Abe-Ouchi, A., Saito, F., Kageyama, M., Braconnot, P., Harrison, S. P., Lambeck, K., Otto-Bliesner, B. L., Peltier, W. R., Tarasov, L., Peterschmitt, J.-Y., and Takahashi, K.: Ice-sheet configuration in the CMIP5/PMIP3 Last Glacial Maximum experiments, Geosci. Model Dev., 8, 3621-3637, https://doi.org/10.5194/gmd-8-36212015, 2015.

Andersen, J. L., Egholm, D. L., Knudsen, M. F., Jansen, J. D., and Nielsen, S. B.: The periglacial engine of mountain erosion - Part 1: Rates of frost cracking and frost creep, Earth Surf. Dynam., 3, 447-462, https://doi.org/10.5194/esurf-3-447-2015, 2015.

Arnold, L., Breon, F. M., and Brewer, S: The earth as an extrasolar planet: the vegetation spectral signature today and during the last Quaternary climatic extrema, Int. J. Astrobiol., 8, 81-94, https://doi.org/10.1017/S1473550409004406, 2009.

Asahi, K.: Equilibrium-line altitudes of the present and Last Glacial Maximum in the eastern Nepal Himalayas and their implications for SW monsoon climate, Quatern. Int., 212, 26-34, https://doi.org/10.1016/j.quaint.2008.08.004, 2010.

Bahrenberg, G., Giese, E., and Nipper, J.: Multivariate Statistik, Statistische Methoden in der Geographie 2, Stuttgart, 1992.

Baker, P. A., Seltzer, G. O., Fritz, S. C., Dunbar, R. B., Grove, M. J., Tapia, P. M., Cross L., Rowe H. D., and Baroda, J. P.: The History of South America Tropical Precipitation for the Past 25,000 Years, Science, 291, 640-643, https://doi.org/10.1126/science.291.5504.640, 2001.

Ballantyne, A. P., Greenwood, D. R., Sinninghe Damste, J. S., Csank, A. Z., Eberle, J. J., and Rybczynski, N.: Significantly warmer Arctic surface temperatures during the Pliocene indicated by multiple independent proxies, Geology, 38, 603-606, 2010.

Banfield, J. F., Barker, W. W., Welch, S. A., and Taunton, A.: Biological impact on mineral dissolution: application of the lichen model to understanding mineral weathering in the rhizophere, $\mathrm{P}$. Natl. Acad. Sci. USA, 96, 3404-3411, 1999.

Barnston, A. G. and Livezey, R. E.: Classification, Seasonality and Persistence of Low-Frequency Atmospheric Circulation Patterns, Mon. Weather Rev., 115, 1083-1126, https://doi.org/10.1175/15200493(1987)115<1083:CSAPOL>2.0.CO;2, 1987.

Barron, J. A. and Anderson, L.: Enhanced Late Holocene ENSO/PDO expression along the margins of the eastern North Pacific, Quatern. Int., 235, 3-12, 2011.

Bendick, R. and Ehlers, T. A.: Extreme localized exhumation at syntaxes initiated by subduction geometry, Geophys. Res. Lett., 41 , 2014GL061026, https://doi.org/10.1002/2014GL061026, 2014.

Bertrand, S., Charlet, F., Charlier, B., Renson, V., and Fagel, N.: Climate variability of southern Chile since the Last Glacial Maximum: a continuous sedimentlogical records from Lago Puyehue $\left(40^{\circ} \mathrm{S}\right)$, J. Paleolimnol., 39, 179-195, https://doi.org/10.1007/s10933-007-9117-y, 2008.

Betancourt, J. L., Latorre C., Rech J. A., Quade J., and Rylander K. A.: A 22,000 Year Record of Monsoonal Precipitation from Northern Chile's Atacama Desert, Science, 289, 15421546, https://doi.org/10.1126/science.289.5484.1542, 2000.

Bigelow, N. H., Brubaker, L. B., Edwards, M. E., Harrison, S. P., Prentice, I. C., Anderson, P. M., Andreev, A. A., Bartlein, P. J., Christensen, T. R., Cramer, W., Kaplan, J. O., Lozhkin, A. V., 
Matveyeva, N. V., Murray, D. V., McGuire, A. D., Razzhivin, V. Y., Ritchie, J. C., Smith, B., Walker, D. A., Gajewski, K., Wolf, V., Holmqvist, B. H., Igarashi, Y., Kremenetskii, K., Paus, A., Pisaric, M. F. J., and Vokova, V. S.: Climate change and Arctic ecosystems I. Vegetation changes north of $55^{\circ} \mathrm{N}$ between the last glacial maximum, mid-Holocene and present, J. Geophys. Res.-Atmos., 108, 1-25, https://doi.org/10.1029/2002JD002558, 2003.

Bird, B. W., Abbott M. B., Rodbell D. T., and Vuille M.: Holocene tropical South American hydroclimate revealed from a decadally resolved lake sediment $\delta 180$ record, Earth Planet. Sc. Lett., 310, 192-202, https://doi.org/10.1016/j.epsl.2011.08.040, 2011.

Bobst, A. L., Lowenstein, T. K., Jordan, T. E., Godfrey, L. V., $\mathrm{Ku}$, T.-L., and Luo, S.: A $106 \mathrm{ka}$ paleoclimate record from drill core of the Salar de Atacama, northern Chile, Palaeogeogr. Palaeocl., 173, 21-42, https://doi.org/10.1016/S00310182(01)00308-X, 2001.

Bohner, J.: General climatic controls and topoclimatic variations in Central and High Asia, Boreas, 35, 279-295, 2006.

Bookhagen, B., Thiede, R. C., and Strecker, M. R.: Late Quaternary intensified monsoon phases control landscape evolution in the northwest Himalaya, Geology, 33, 149-152, https://doi.org/10.1130/G20982.1, 2005.

Boos, W. R. and Kuang, Z.: Dominant control of the South Asian monsoon by orographic insulation versus plateau heating, Nature, 463, 218-222, 2010.

Braconnot, P., Otto-Bliesner, B., Harrison, S., Joussaume, S., Peterchmitt, J.-Y., Abe-Ouchi, A., Crucifix, M., Driesschaert, E., Fichefet, Th., Hewitt, C. D., Kageyama, M., Kitoh, A., Laîné, A., Loutre, M.-F., Marti, O., Merkel, U., Ramstein, G., Valdes, P., Weber, S. L., Yu, Y., and Zhao, Y.: Results of PMIP2 coupled simulations of the Mid-Holocene and Last Glacial Maximum Part 1: experiments and large-scale features, Clim. Past, 3, 261277, https://doi.org/10.5194/cp-3-261-2007, 2007.

Braun, J.: A simple model for regolith formation by chemical weathering: Regolith Formation, J. Geophys. Res.-Earth, 121, 2140-2171, https://doi.org/10.1002/2016JF003914, 2016.

Caves, J.: Late Miocene Uplift of the Tian Shan and Altai and Reorganization of Central Asia Climate, GSA Today, https://doi.org/10.1130/gsatg305a.1, 2017.

CLIMAP Project Members: Seasonal Reconstruction of the Earth's Surface at the Last Glacial Maximum, Map and Chart Series, Vol. 36, Geological Society of America, 18 pp., 1981.

Cohen, S. J.: Bringing the global warming issue close to home: The challenge of regional impact studies, B. Am. Meteorol. Soc., 71, 520-526, 1990.

D'Agostino, K., Seltzer, G., Baker, P., Fritz, S., and Dunbar, R.: Late-Quaternary lowstands of Lake Titicaca: evidence from high-resolution seismic data, Palaeogeogr. Palaeocl., 179, 97111, https://doi.org/10.1016/S0031-0182(01)00411-4, 2002.

De Batist, M., Fagel N., Loutre M. F., and Chapron E.: A 17,900-year multi-proxy lacustrine record of Lago Puyehue (Chilean Lake District): introduction, J. Paleolimnol., 39, 151161, https://doi.org/10.1007/s10933-007-9113-2, 2007.

Delunel, R., van der Beek, P. A., Carcaillet, J., Bourlès, D. L., and Valla, P. G.: Frost-cracking control on catchment denudation rates: Insights from in situ produced $10 \mathrm{Be}$ concentrations in stream sediments (Ecrins-Pelvoux massif,
French Western Alps), Earth Planet. Sc. Lett., 293, 72-83, https://doi.org/10.1016/j.epsl.2010.02.020, 2010.

DeMenocal, P., Ortiz, J., Guilderson, T., Adkins, J., Samthein, M., Baker, L., and Yarusinsky, M.: Abrupt onset and termination of the African Humid Period:: rapid climate responses to gradual insolation forcing, Quaternary Sci. Rev., 19, 347-361, https://doi.org/10.1016/S0277-3791(99)00081-5, 2000.

Demske, D., Tarasov, P. E., Wünnemann, B., and Riedel, F.: Late glacial and Holocene vegetation, Indian monsoon and westerly circulation in the Trans-Himalaya recorded in the lacustrine pollen sequence from Tso Kar, Ladakh, NW India, Palaeogeogr. Palaeocl., 279, 172-185, https://doi.org/10.1016/j.palaeo.2009.05.008, 2009.

de Porras, M. E., Maldonado, A., Abarzua, A. M., Cardenas, M. L., Francois, J. P., Martel-Cea, A., Stern, C. R., Mendez, C., and Reyes, O.: Postglacial vegetation, fire and climate dynamics at Central Chilean Patagonia (Lake Shaman, $44^{\circ} \mathrm{S}$ ), Quaternary Sci. Rev., 50, 71-85, https://doi.org/10.1016/j.quascirev.2012.06.015 2012.

de Porras, M. E., Maldonado, A., Quintana, F. A., MartelCea, A., Reyes, O., and Méndez, C.: Environmental and climatic changes in central Chilean Patagonia since the Late Glacial (Mallín El Embudo, 44 S), Clim. Past, 10, 1063-1078, https://doi.org/10.5194/cp-10-1063-2014, 2014.

Dettman, D. L., Fang, X. M., Garzione, C. N., and Li, J. J.: Upliftdriven climate change at $12 \mathrm{Ma}$ : a long delta O-18 record from the NE margin of the Tibetan plateau, Earth Planet. Sc. Lett., 214, 267-277, 2003.

Diaz, F. P., Latorre, C., Maldonado, A., Quade, J., and Betancourt, J. L.: Rodent middens reveal episodic, longdistance plant colonizations across the hyperarid Atacama Desert over the last 34,000 years, J. Biogeogr., 39, 510-525, https://doi.org/10.1111/j.1365-2699.2011.02617.x, 2012.

Dietrich, S., Werner, M., Spangehl, T., and Lohmann, G.: Influence of orbital forcing and solar activity on water isotopes in precipitation during the mid- and late Holocene, Clim. Past, 9, 13-26, https://doi.org/10.5194/cp-9-13-2013, 2013.

Dietrich, W. E. and Perron, J. T.: The search for a topographic signature of life, Nature, 439, 411-418, https://doi.org/10.1038/nature04452, 2006.

Dowsett, H. J., Robinson, M., Haywood, A., Salzmann, U., Hill, D., Sohl, L., Chandler, M., Williams, M., Foley, K., and Stoll, D.: The PRISM3D paleoenvironmental reconstruction, Stratigraphy, 7, 123-139, 2010.

Egholm, D. L., Nielsen, S. B., Pedersen, V. K., and Lesemann, J.,: Glacial efects limiting moutain height, Nature, 460, 884-887, 2009.

Ehlers, T. A. and Poulsen, C. J.: Influence of Andean uplift on climate and paleoaltimetry estimates, Earth Planet. Sc. Lett., 281, 238-248, 2009.

Etheridge, D. M., Steele, L., Langenfelds, R., Francey, R., Barnola, J., and Morgan, V.:, Natural and anthropogenic changes in atmospheric $\mathrm{CO}_{2}$ over the last 1000 years from air in Antarctic ice and firn, J. Geophys. Res., 101, 4115-4128, 1996.

Etheridge, D. M., Steele, L., Francey, R., and Langenfelds, R.: Atmospheric methane between 1000 a.d. and present: evidence of anthropogenic emissions and climatic variability, J. Geophys. Res., 103, 15979-15993, 1998. 
Feng, R. and Poulsen, C. J.: Refinement of Eocene lapse rates, fossil-leaf altimetry, and North American Cordilleran surface elevation estimates, Earth Planet. Sc. Lett., 436, 130-141, https://doi.org/10.1016/j.epsl.2015.12.022, 2016.

Feng, R., Poulsen, C. J., Werner, M., Chamberlain, C. P., Mix, H. T., and Mulch, A.: Early Cenozoic evolution of topography, climate, and stable isotopes in precipitation in the North American Cordillera, Am. J. Sci., 313, 613-648, 2013.

Feng, R., Poulsen, C. J., and Werner, M.: Tropical circulation intensification and tectonic extension recorded by Neogene terrestrial d180 records of the western United States, Geology, 44, 971974, https://doi.org/10.1130/G38212.1, 2016.

Fritz, S. C., Baker, P. A., Lowenstein, T. K., Seltzer, G. O., Rigsby, C. A., Dwyer, G. S., Tapia, P. M., Arnold, K. K., Ku, T. L., and Luo, S: Hydrologic variation during the last 170,000 years in the southern hemisphere tropics of South America, Quaternary Res., 61, 95-104, https://doi.org/10.1016/j.yqres.2003.08.007, 2004.

Gasse, F., Arnold, M., Fontes, J. C., Fort, M., Gibert, E., Huc, A., Li, B., Li, Y., Liu, Q., Melleres, F., Van Campo, E., Wang, F., and Zhang, Q.: A 13,000-year climate record from western Tibet, Nature, 353, 742-745, https://doi.org/10.1016/j.quaint.2006.02.001, 1991.

Gayo, E. M., Latorre, C., Santoro, C. M., Maldonado, A., and De Pol-Holz, R.: Hydroclimate variability in the low-elevation Atacama Desert over the last 2500 yr, Clim. Past, 8, 287-306, https://doi.org/10.5194/cp-8-287-2012, 2012.

Gierz, P., Lohmann, G., and Wei, W.: Response of Atlantic Overturning to future warming in a coupled atmosphereocean-ice sheet model, Geophys. Res. Lett., 42, 6811-6818, https://doi.org/10.1002/2015GL065276, 2015.

Gilli, A., Ariztegui, D., Bradbury, J. P., Kelts, K. R., Markgraf, V., and McKenzie, J. A.: Tracking abrupt climate change in the Southern Hemisphere: a seismic stratigraphic study of Lago Cardiel, Argentina (49 $\left.{ }^{\circ} \mathrm{S}\right)$, Terra Nova, 13, 443-448, https://doi.org/10.1046/j.1365-3121.2001.00377.x, 2001.

Glotzbach, C., van der Beek, P., Carcaillet, J., and Delunel, R.: Deciphering the driving forces of erosion rates on millennial to million-year timescales in glacially impacted landscapes: An example from the Western Alps, J. Geophys. Res.-Earth, 118, 1491-1515, 2013.

Gong, X., Knorr, G., Lohmann, G., and Zhang, X.: Dependence of abrupt Atlantic meridional ocean circulation changes on climate background states, Geophys. Res. Lett., 40, 3698-3704, https://doi.org/10.1002/grl.50701, 2013.

Grosjean, M., Van Leeuwen, J., Van der Knaap, W., Geyh, M., Ammann, B., Tanner, W., Messerli, B., Núñez, L., ValeroGarcés, B., and Veit, H.: A 22,000 14C year BP sediment and pollen record of climate change from Laguna Miscanti $\left(23^{\circ} \mathrm{S}\right)$, northern Chile, Global Planet. Change, 28, 35-51, https://doi.org/10.1016/S0921-8181(00)00063-1, 2001.

Gyssels, G., Poesen, J., Bochet, E., and Li, Y.: Impact of plant roots on the resistance of soils to erosion by water: a review, Prog. Phys. Geog., 29, 189-217, https://doi.org/10.1191/0309133305pp443ra, 2005.

Hansen, B. C. S., Seltzer, G. O., and Wright Jr., H. E.: Late Quaternary vegetational change in the central Peruvian Andes, Palaeogeogr. Palaeocl., 109, 263-285, https://doi.org/10.1016/00310182(94)90179-1, 1994.
Harris, I., Jones, P. D., Osborn, T. J., and Lister, D. H.: Updated high-resolution grids of monthly climatic observations - the CRU TS3.10 Dataset, Int. J. Climatol., 34, 623-642, https://doi.org/10.1002/joc.3711, 2013.

Harrison, S. P., Yu, G., Takahara, H., and Prentice, I. C.: Palaeovegetation - Diversity of temperate plants in east Asia, Nature, 413, 129-130, 2001.

Harrison, S. P., Bartlein, P. J., Brewer, S., Prentice, I. C., Boyd, M., Hessler, I., Holmgren, K., Izumi, K., and Willis, K.: Climate model benchmarking with glacial and mid-Holocene climates, Clim. Dynam., 43, 671-688, doi 10.1007/s00382-013-1922-6, 2013.

Haywood, A. M., Valdes, P. J., and Sellwood, B. W.: Global scale palaeoclimate reconstruction of the middle Pliocene climate using the UKMO GCM: initial results, Global Planet. Change, 25, 239-256, 2000.

Haywood, A. M., Dowsett, H. J., Otto-Bliesner, B., Chandler, M. A., Dolan, A. M., Hill, D. J., Lunt, D. J., Robinson, M. M., Rosenbloom, N., Salzmann, U., and Sohl, L. E.: Pliocene Model Intercomparison Project (PlioMIP): experimental design and boundary conditions (Experiment 1), Geosci. Model Dev., 3, 227-242, https://doi.org/10.5194/gmd-3-227-2010, 2010.

Haywood, A. M., Hill, D. J., Dolan, A. M., Otto-Bliesner, B. L., Bragg, F., Chan, W.-L., Chandler, M. A., Contoux, C., Dowsett, H. J., Jost, A., Kamae, Y., Lohmann, G., Lunt, D. J., Abe-Ouchi, A., Pickering, S. J., Ramstein, G., Rosenbloom, N. A., Salzmann, U., Sohl, L., Stepanek, C., Ueda, H., Yan, Q., and Zhang, Z.: Large-scale features of Pliocene climate: results from the Pliocene Model Intercomparison Project, Clim. Past, 9, 191-209, https://doi.org/10.5194/cp-9-191-2013, 2013.

Herman, F., Seward, D., Valla, P. G., Carter, A., Kohn, B., Willett, S. D., and Ehlers, T. A.: Worldwide acceleration of mountain erosion under a cooling climate, Nature, 504, 423-426, https://doi.org/10.1038/nature12877, 2013.

Herzschuh, U., Kuerschner, H., and Mischke, S.: Temperature variability and vertical vegetation belt shifts during the last $\sim 50,000 \mathrm{yr}$ in the Qilian Mountains (NE margin of the Tibetan Plateau, China), Quaternary Res., 66, 133-146, https://doi.org/10.1016/j.yqres.2006.03.001, 2006a.

Herzschuh, U., Winter, K., Wuennemann, B., and Li, S.: A general cooling trend on the central Tibetan Plateau throughout the Holocene recorded by the lake Zigetang pollen spectra, Quatern. Int., 154, 113-121, https://doi.org/10.1016/j.quaint.2006.02.005, 2006b.

Herzschuh, U., Kramer A., Mischke S., and Zhang C.: Quantitative climate and vegetation trends since the late glacial on the northeastern Tibetan Plateau deduced from Koucha lake pollen spectra, Quaternary Res., 71, 162-171, https://doi.org/10.1016/j.yqres.2008.09.003, 2009.

Hillenbrand, C.-D. and Fütterer, D. K.: Neogene to Quaternary deposition of opal on the continental rise west of the Antarctic Peninsula, ODP Leg 178, Sites 1095, 1096, and 1101, in: Proceedings of the Ocean Drilling Programme, Scientific Results, 178, edited by: Barker, P. F., Camerlenghi, A., Acton, G. D., and Ramsay, A. T. S., Texas A and M University, College Station, Texas, 1-40 (CD-ROM), 2002.

Hillyer, R., Valencia, B. G., Bush, M. B., Silman, M. R., and Steinitz-Kannan, M.: A 24,700-yr paleolimnological his- 
tory from the Peruvian Andes, Quaternary Res., 71, 71-82, https://doi.org/10.1016/j.yqres.2008.06.006, 2009.

Hobley, D. E., Sinclair, H. D., and Cowie, P. A.: Processes, rates, and time scales of fluvial response in an ancient postglacial landscape of the northwest Indian Himalaya, Geol. Soc. Am. Bull., 122, 1569-1584, 2010.

Hodell, D. A., Brenner, M., Kanfoush, S. L., Curtis, J. H., Stoner, J. S., Song, X., Wu, Y., and Whitmore, T. J.: Paleoclimate of southwestern China for the past 50,000 yr inferred from lake sediment records, Quaternary Res., 52, 369-380, https://doi.org/10.1006/qres.1999.2072, 1999.

Hu, G., Yi, C.-L., Zhang, J.-F., Liu, J.-L., Jiang, T., and Qin, X.: Optically stimulated luminescence dating of a moraine and a terrace in Laohugou valley, western Qilian Shan, northeastern Tibet, Quatern. Int., 321, 37-49, https://doi.org/10.1016/j.quaint.2013.12.019, 2014.

Insel, N., Poulsen, C. J., and Ehlers, T. A.: Influence of the Andes Mountains on South American moisture transport, convection, and precipitation, Clim. Dynam., 35, 1477-1492, 2010.

Jeffery, M. L., Ehlers, T. A., Yanites, B. J., and Poulsen, C. J.: Quantifying the role of paleoclimate and Andean Plateau uplift on river incision: paleoclimate role in river incision, J. Geophys. Res.-Earth, 118, 852-871, https://doi.org/10.1002/jgrf.20055, 2013.

Jenny, B., Valero-Garces, B. L., Urrutia, R., Kelts, K., Veit, H., and Geyh, M.: Moisture changes and fluctuations of the Westerlies in Mediterranean Central Chile during the last 2000 years: The Laguna Aculeo record ( $33^{\circ} 50^{\prime} \mathrm{S}$ ), Quatern. Int., 87, 3-18, https://doi.org/10.1016/S1040-6182(01)00058-1, 2002a.

Jenny, B., Valero-Garcés, B. L., Villa-Martínez, R., Urrutia, R., Geyh, M. A., and Veit, H.: Early to Mid-Holocene Aridity in Central Chile and the Southern Westerlies: The Laguna Aculeo Record ( $34^{\circ} \mathrm{S}$ ), Quaternary Res., 58, 160-170, https://doi.org/10.1006/qres.2002.2370, 2002b.

Jungclaus, J. H., Lorenz, S. J., Timmreck, C., Reick, C. H., Brovkin, V., Six, K., Segschneider, J., Giorgetta, M. A., Crowley, T. J., Pongratz, J., Krivova, N. A., Vieira, L. E., Solanki, S. K., Klocke, D., Botzet, M., Esch, M., Gayler, V., Haak, H., Raddatz, T. J., Roeckner, E., Schnur, R., Widmann, H., Claussen, M., Stevens, B., and Marotzke, J.: Climate and carbon-cycle variability over the last millennium, Clim. Past, 6, 723-737, https://doi.org/10.5194/cp-6-723-2010, 2010.

Junginger, A., Roller, S., Olaka, L. A., and Trauth, M. H.: The effects of solar irradiation changes on the migration of the Congo Air Boundary and water levels of paleoLake Suguta, Northern Kenya Rift, during the African $\mathrm{Hu}-$ mid Period (15-5 ka BP), Palaeogeogr. Palaeocl., 396, 1-16, https://doi.org/10.1016/j.palaeo.2013.12.007, 2014.

Kaiser, J., Schefuss, E., Lamy, F., Mohtadi, M., and Hebbeln, D.: Glacial to Holocene changes in sea surface temperature and coastal vegetation in north central Chile: high versus low latitude forcing, Quaternary Sci. Rev., 27, 2064-2075, https://doi.org/10.1016/j.quascirev.2008.08.025, 2008.

Kalnay, E., Kanamitsu, M., Kistler, R., Collins, W., Deaven, D., Gandin, L., Iredell, M., Saha, S., White, G., Woollen, J., Zhu, Y., Chelliah, M., Ebisuzaki, W., Higgins, W., Janowiak, J., Mo, K. C., Ropelewski, C., Wang, J., Leetmaa, A., Reynolds, R., Jenne, R., and Joseph, D.: The NCEP/NCAR 40-year reanalysis project, B. Am. Meteorol. Soc., 77, 437-471, 1996.
Kashiwaya, K., Masuzawa, T., Morinaga, H., Yaskawa, K., Yuan, B. Y., Liu, J. Q., and Gu, Z.: Changes in hydrological conditions in the central Qing-Zang (Tibetan) Plateau inferred from lake bottom sediments, Earth Planet. Sc. Lett., 135, 31-39, https://doi.org/10.1016/0012-821X(95)00136-Z, 1995.

Kent-Corson, M., Sherman, L., Mulch, A., and Chamberlain, C.: Cenozoic topographic and climatic response to changing tectonic boundary conditions in Western North America, Earth Planet. Sc. Lett., 252, 453-466, https://doi.org/10.1016/j.epsl.2006.09.049, 2006.

Kirchner, J. W., Finkel, R. C., Riebe, C. S., Granger, D. E., Clayton, J. L., King, J. G., and Megahan, W. F.: Mountain erosion over 10 yr, 10 k.y., and 10 m.y. time scales, Geology, 29, 591-594, 2001.

Kistler, R., Collins, W., Saha, S., White, G., Woollen, J., Kalnay, E., Chelliah, M., Ebisuzaki, W., Kanamitsu, M., Kousky, V., Van den Dool, H., Jenne, R., and Fiorino, M.: The NCEP-NCAR 50-Year Reanalysis: Monthly Means CD-ROM and Documentation, B. Am. Meteorol. Soc., 82, 247-267, 2001.

Knorr, G., Butzin, M., Micheels, A., and Lohmann, G.: A Warm Miocene Climate at Low Atmospheric $\mathrm{CO}_{2}$ levels, Geophys. Res. Lett., 38, L20701, https://doi.org/10.1029/2011GL048873, 2011.

Koons, P. O., Zeitler, P. K., and Hallet, B.: 5.14 Tectonic Aneurysms and Mountain Building, in: Treatise on Geomorphology, Elsevier, 318-349, 2013.

Kotlia, B. S., Sharma, C., Bhalla, M. S., Rajagopalan, G.,. Subrahmanyam, K., Bhattacharya, A., and Valdiya, K. S.: Paleoclimatic conditions in the late Pleistocene Wadda Lake, eastern Kumaun Himalaya (India), Palaeogeogr. Palaeocl., 162, 105-118, https://doi.org/10.1016/S0031-0182(00)00107-3, 2000.

Kramer, A., Herzschuh, U., Mischke, S., and Zhang, C.: Late glacial vegetation and climate oscillations on the southeastern Tibetan Plateau inferred from the lake Naleng pollen profile, Quaternary Res., 73, 324-335, https://doi.org/10.1016/j.yqres.2009.12.003, 2010.

Kraus, H.: Die Atmosphäre der Erde, Eine Einführung in die Meteorologie, Berlin, 2001.

Kutzbach, J. E., Guetter, P. J., Ruddiman, W. F., and Prell, W. L.: Sensitivity of Climate to Late Cenozoic Uplift in Southern Asia and the American West - Numerical Experiments, J. Geophys. Res.-Atmos., 94, 18393-18407, 1989.

Kutzbach, J. E., Prell, W. L., and Ruddiman, W. F.: Sensitivity of Eurasian Climate to Surface Uplift of the Tibetan Plateau, J. Geol., 101, 177-190, 1993.

Lamy, F. and Kaiser. J.: Past Climate Variability in South America and Surrounding Regions, Chapter 6: Glacial to Holocene Paleoceanographic and Continental Paleoclimate Reconstructions Based on ODP Site 1233/GeoB 3313 Off southern Chile, 2009.

Lamy, F., Hebbeln, D., and Wefer, G.: High Resolution Marine Record of Climatic Change in Mid-latitude Chile during the Last 28,000 Years Based on Terrigenous Sediment Parameters, Quaternary Res., 51, 83-93, https://doi.org/10.1006/qres.1998.2010, 1999.

Lamy, F., Klump, J., Hebbeln, D., and Wefer, G.: Late Quaternary rapid climate change in northern Chile, Terra Nova, 12, 8-13, https://doi.org/10.1046/j.1365-3121.2000.00265.x, 2000.

Lamy, F., Rühlemann, C., Hebbeln, D., and Wefer, G.: High- and low-latitude climate control on the position of the southern Peru- 
Cihle Current during the Holocene, Paleoceanography, 17, 16-116-10, https://doi.org/10.1029/2001PA000727, 2002.

Latorre, C., Betancourt, J., Rylander, K., and Quade, J.: Vegetation invasions into absolute desert: A $45000 \mathrm{yr}$ rodent midden record from the Calama-Salar de Atacama basins, northern Chile (lat $22^{\circ}-24^{\circ} \mathrm{S}$ ), Geol. Soc. Am. Bull., 114, 349-366, https://doi.org/10.1130/00167606(2002)114<0349:VIIADA>2.0.CO;2, 2002.

Latorre, C., Betancourt, J. L., Rylander, K. A., Quade, J., and Matthei, O.: A vegetation history from the arid prepuna of northern Chile $\left(22-23^{\circ} \mathrm{S}\right)$ over the last 13500 years, Palaeogeogr. Palaeocl., 194, 223-246, https://doi.org/10.1016/S00310182(03)00279-7, 2003.

Latorre, C., Betancourt, J. L., and Arroyo, M. T. K.: Late Quaternary vegetation and climate history of a perennial river canyon in the Río Salado basin $\left(22^{\circ} \mathrm{S}\right)$ of northern Chile, Quaternary Res., 65, 450-466, https://doi.org/10.1016/j.yqres.2006.02.002, 2006.

Lease, R. O. and Ehlers, T. A.: Incision into the Eastern Andean Plateau During Pliocene Cooling, Science, 341, 774-776, https://doi.org/10.1126/science.1239132, 2013.

Lechler, A. and Niemi, N.: Sedimentologic and isotopic constraints on the Paleogene paleogeography and paleotopography of the southern Sierra Nevada, California, Geology, 39, 379-382, https://doi.org/10.1130/g31535.1, 2011.

Lechler, A., Niemi, N., Hren, M., and Lohmann, K.: Paleoelevation estimates for the northern and central proto-Basin and Range from carbonate clumped isotope thermometry, Tectonics, 32, 295-316, https://doi.org/10.1002/tect.20016, 2013.

Legates, D. R. and Willmott, C. J.: Mean Seasonal and Spatial Variability in Gauge-Corrected, Global Precipitation, Int. J. Climatol., 10, 111-127, https://doi.org/10.1002/joc.3370100202, 1990.

Li, J., Ehlers, T. A., Werner, M., Mutz, S. G., Steger, C., and Paeth, H.: Late quarternary climate, precipitation $\delta^{18} \mathrm{O}$, and Indian monsoon variations over the Tibetan Plateau, Earth Planet. Sc. Lett., 457, 412-422, 2017.

Licht, A., Quade, J., Kowler, A., de los Santos, M., Hudson, A., Schauer, A., Huntington, K., Copeland, P., and Lawton, T.: Impact of the North American monsoon on isotope paleoaltimeters: Implications for the paleoaltimetry of the American southwest, Am. J. Sci., 317, 1-33, https://doi.org/10.2475/01.2017.01, 2017.

Liu, K., Yao, Z., and Thompson, L. G.: A pollen record of Holocene climatic changes from the Dunde ice cap, QinghaiTibetan Plateau, Geology, 26, 135-138, 1998.

Liu, X., Colman, S. M., Brown, E. T., An, Z., Zhou, W., Jull, A. J. T., Huang, Cheng, Y., P., Liu, W., and Xu, H.: A climate threshold at the eastern edge of the Tibetan plateau, Geophys. Res. Lett., 41, 5598-5604, https://doi.org/10.1002/2014GL060833, 2014.

Lohmann, G., Pfeiffer, M., Laepple, T., Leduc, G., and Kim, J.-H.: A model-data comparison of the Holocene global sea surface temperature evolution, Clim. Past, 9, 180-1839, https://doi.org/10.5194/cp-9-1807-2013, 2013.

Lorenz, S. J. and Lohmann, G.: Acceleration technique for Milankovitch type forcing in a coupled atmosphere-ocean circulation model: method and application for the Holocene, Clim. Dynam., 23, 727-743, https://doi.org/10.1007/s00382-004-0469-y, 2004

Maldonado, A. and Villagrán, C.: Climate variability over the last $9900 \mathrm{cal}$ yr BP from a swamp forest pollen record along the semiardi coast of Chile, Quaternary Res., 66, 146-258, https://doi.org/10.1016/j.yqres.2006.04.003, 2006.

Maldonado, A. J., Betancourt, J. L., Latorre, C., and Villagrán, C.: Pollen analyses from a 50000-yr rodent midden series in the southern Atacama Desert ( $25^{\circ} 30^{\prime}$ S), J. Quaternary Sci., 20, 493-507, https://doi.org/10.1002/jqs.936, 2005.

Maldonado, A., Méndez, C., Ugalde, P., Jackson, D., Seguel, R., and Latorre, C.: Early Holocene climate change and human occupation along the semiarid coast of north-central Chile, J. Quaternary Sci., 25, 985-988, https://doi.org/10.1002/jqs.1385, 2010.

Markgraf, V., Bradbury, J. P., Schwalb, A., Burns, S., Stern, C., Ariztegui, D., Gilli, D., Anselmetti, F. S., Stine, S., and Maidana, N.: Holocene palaeoclimates of southern Patagonia: limnological and environmental history of Lago Cardiel, Argentina, Holocene, 13, 581-591, https://doi.org/10.1191/0959683603hl648rp, 2003.

Markgraf, V., Whitlock, C., and Haberle, S.: Vegetation and fire history during the last 18,000 cal yr B.P. in Southern Patagonia: Mallín Pollux, Coyhaique, Province Aisén ( $45^{\circ} 41^{\prime} 30^{\prime}$ S, $71^{\circ}$ 50'30” W, 640 m elevation), Palaeogeogr. Palaeocl., 254, 492507, https://doi.org/10.1016/j.palaeo.2007.07.008, 2007.

Maroon, E. A., Frierson, D. M. W., and Battisti, D. S.: The tropical precipitation response to Andes topography and ocean heat fluxes in an aquaplanet model, J. Climate, 28, 381-398, https://doi.org/10.1175/JCLI-D-14-00188.1, 2015.

Maroon, E. A., Frierson, D. M. W., Kang, S. M., and Scheff, J.: The precipitation response to an idealized subtropical continent, J. Climate, 29, 4543-4564, https://doi.org/10.1175/JCLI-D-150616.1, 2016.

Marshall, J. A., Roering, J. J., Bartlein, P. J., Gavin, D. G., Granger, D. E., Rempel, A. W., Praskievicz, S. J., and Hales, T. C.: Frost for the trees: Did climate increase erosion in unglaciated landscapes during the late Pleistocene?, Sci. Adv., 1, 1-10, 2015.

Marston, R. A.: Geomorphology and vegetation on hillslopes: Interactions, dependencies, and feedback loops, Geomorphology, 116, 206-217, https://doi.org/10.1016/j.geomorph.2009.09.028, 2010.

Matsuoka, N.: Solifluction rates, processes and landforms: A global review, Earth Sci. Rev., 55, 107-134, 2001.

Matsuoka, N. and Murton, J.: Frost weathering: Recent advances and future directions, Permafrost Periglac., 19, 195-210, 2008.

Maussion, F., Scherer, D., Mölg, T., Collier, E., Curio, J., and Finkelnburg, R.: Precipitation seasonality and variability over the Tibetan Plateau as resolved by the High Asia Reanalysis, J. Climate, 27, 1910-1927, https://doi.org/10.1175/JCLI-D-13$00282.1,2014$.

Méndez, C., Gil, A., Neme, G., Nuevo Delaunay, A., Cortegoso, V., Huidobro, C., Durán, and Maldano, A.: Mid Holocene radiocarbon ages in the Subtropical Andes $\left(\sim 29^{\circ}-35^{\circ} \mathrm{S}\right)$, climatic change an implicaton for human space organization, Quatern. Int., 356, 15-26, https://doi.org/10.1016/j.quaint.2014.06.059, 2015.

Meehl, G. A., Covey, C., Delworth, T., Latif, M., McAvaney, B., Mitchell, J. F. B., Stouffer, R. J., and Taylor, K. E.: The WCRP CMIP3 multi-model dataset: A new era in climate change research, B. Am. Meterol. Soc., 88, 1383-1394, 2007.

Mesinger, F., DiMego, G., Kalnay, E., Mitchell, K., Shafran, P.C., Ebisuzaki, W., Jovic, D., Woollen, J., Rogers, E., Berbery, E.H., Ek, M.B., Fan, Y., Grumbine, R., Higgins, W., Li, H., Lin, Y., Manikin, G., Parrish, D., and Shi, W.: North Ameri- 
can Regional Reanalysis, B. Am. Meteorol. Soc., 87, 343-360, https://doi.org/10.1175/BAMS-87-3-343, 2006.

Methner, K., Fiebig, J., Wacker, U., Umhoefer, P., Chamberlain, C., and Mulch, A.: Eocene-Oligocene proto-Cascades topography revealed by clumped $(\Delta 47)$ and oxygen isotope $(\delta 180)$ geochemistry (Chumstick Basin, WA, USA), Tectonics, 35, 546564, https://doi.org/10.1002/2015tc003984, 2016.

Mischke S., Kramer M., Herzschuh U., Shang H., Erzinger J., and Zhang C.: Reduced early holocene moisture availability in the Bayan Har Mountains, northeastern Tibetan Plateau, inferred from a multi-proxy lake record, Palaeogeogr. Palaeocl., 267, 5976, https://doi.org/10.1016/j.palaeo.2008.06.002, 2008.

Molnar, P. and England, P.: Late Cenozoic uplift of mountain ranges and global climate change: chicken or egg?, Nature, 346, 29-34, 1990.

Molnar, P., Boos, W. R., and Battisti, D. S.: Orographic Controls on Climate and Paleoclimate of Asia: Thermal and Mechanical Roles for the Tibetan Plateau, Annu. Rev. Earth Planet. Sc., 38, 77-102, 2010.

Montgomery, D. R.: Slope distributions, threshold hillslopes, and steady-state topography, Am. J. Sci., 301, 432-454, 2001.

Montgomery, D. R., Balco, G., and Willett, S.D.: Climate, tectonics, and the morphology of the Andes, Geology, 29, 579-582, 2001.

Moon, S., Chamberlain, C. P., Blisniuk, K., Levine, N., Rood, D. H., and Hilley, G. E.: Climatic control of denudation in the deglaciated landscape of the Washington Cascades, Nat. Geosci., 4, 469-473, 2011.

Moreno, A., Santoro, C. M., and Latorre, C.: Climate change and human occupation in the northernmost Chilean Altiplano over the last ca. 11500 cal. a BP, Quaternary Sci., 24, 373-382, https://doi.org/10.1002/jqs.1240, 2009.

Morinaga, H., Itota, C., Isezaki, N., Goto, H., Yaskawa, K., Kusakabe, M., Liu, J., Gu, Z., Yuan, B., and Cong, S.: Oxygen-18 and carbon-13 records for the last 14,000 years from lacustrine carbonates of Siling-Co (lake) in the Qinghai-Tibetan Plateau, Geophys. Res. Lett., 20, 2909-2912, https://doi.org/10.1029/93GL02982, 1993.

Morrill, C., Overpeck, J. T., Cole, J. E., Liu, K., Shen, C., and Tang, L.: Holocene variations in theAsian monsoon inferred from the geochemistry of lake sediments in central Tibet, Quaternary Res., 65, 232-243, https://doi.org/10.1016/j.yqres.2005.02.014, 2006.

Moulton, K. L. and Berner, R. A.: Quantification of the effect of plants on weathering: studies in Iceland, Geology, 26, 895-898, 1998.

Muegler, I., Gleixner, G., Guenther, F., Maeusbacher, R., Daut, G., Schuett, B., Berking, J., Schwalb, A., Schwark, L, Xu, B., Yao, T., Zhu, L., and Yi, C.: A multi-proxy approach to reconstruct hydrological changes and Holocene climate development of Nam Co, Central Tibet, J. Paleolimnol., 43, 625-648, https://doi.org/10.1007/s10933-009-9357-0, 2010.

Mujica, M. I., Latorre, C., Maldonado, A., González-Silvestre, L., Pinto, R., De Pol-Holz, R., and Santoro, C. M.: Late Quaternary climate change, relict populations and presentday refugia in the northern Atacama Desert: a case study from Quebrada La Higuera $\left(18^{\circ} \mathrm{S}\right)$, J. Biogeogr., 42, 76-88, https://doi.org/10.1111/jbi.12383, 2015.

Mulch, A., Sarna-Wojcicki, A., Perkins, M., and Chamberlain, C.: A Miocene to Pleistocene climate and elevation record of the
Sierra Nevada (California), P. Natl. Acad. Sci. USA, 105, 68196824, https://doi.org/10.1073/pnas.0708811105, 2008.

Mulch, A., Chamberlain, C., Cosca, M., Teyssier, C., Methner, K., Hren, M., and Graham, S.: Rapid change in high-elevation precipitation patterns of western North America during the Middle Eocene Climatic Optimum (MECO), Am. J. Sci., 315, 317-336, https://doi.org/10.2475/04.2015.02, 2015.

Mutz, S. G., Ehlers, T. A., Li, J., Steger, C., Peath, H., Werner, M., and Poulsen, C. J.: Precipitation $\delta^{18} \mathrm{O}$ over the South Asia Orogen from ECHAM5-wiso Simulation: Statistical Analysis of Temperature, Topography and Precipitation, J. Geophys. Res.-Atmos., 121, 9278-9300, https://doi.org/10.1002/2016JD024856, 2016.

Nishimura, M., Matsunaka, T., Morita, Y., Watanabe, T., Nakamura, T., Zhu, L., Nara, W. F., Imai, A., Izutsu, Y., and Hasuike, N.: Paleoclimatic changes on the southern Tibetan Plateau over the past 19,000 years recorded in lake Pumoyum Co, and their implications for the southwest monsoon evolution, Palaeogeogr. Palaeocl., 396, 75-92, https://doi.org/10.1016/j.palaeo.2013.12.015, 2014.

Otto-Bliesner, B. L., Brady, C. B., Clauzet, G., Tomas, R., Levis, S., and Kothavala, Z.: Last Glacial Maximum and Holocene Climate in CCSM3, J. Climate, 19, 2526-2544, 2006.

Paeth, H.: Key Factors in African Climate Change Evaluated by a Regional Climate Model, Erdkunde, 58, 290-315, 2004.

Peel, M. C., Finlayson, B. L., and McMahon, T. A.: Updated world map of the Köppen-Geiger climate classification, Hydrol. Earth Syst. Sci., 11, 1633-1644, https://doi.org/10.5194/hess-11-16332007, 2007.

Pfeiffer, M. and Lohmann, G.: Greenland Ice Sheet influence on Last Interglacial climate: global sensitivity studies performed with an atmosphere-ocean general circulation model, Clim. Past, 12, 1313-1338, https://doi.org/10.5194/cp-12-1313-2016, 2016.

Pickett, E. J., Harrison, S. P., Flenley, J., Grindrod, J., Haberle, S., Hassell, C., Kenyon, C., MacPhail, M., Martin, H., Martin, A. H., McKenzie, M., Newsome, J. C., Penny, D., Powell, J., Raine, J. I., Southern, W., Stevenson, J., Sutra, J.-P., Thomas, I., van der Kaars, S., and Ward, J.: Pollen-based reconstructions of biome distributions for Australia, South-East Asia and the Pacific (SEAPAC region) at 0,6000 and 18,000 14C years B.P. J. Biogeogr., 31, 1381-1444, https://doi.org/10.1111/j.13652699.2004.01001.x, 2004.

Pingel, H., Mulch, A., Alonso, R., Cottle, J., Hynek, S., Poletti, J., Rohrmann, A., Schmitt, A., Stockli, D., and Strecker, M.: Surface uplift and convective rainfall along the southern Central Andes (Angastaco Basin, NW Argentina), Earth Planet. Sc. Lett., 440, 33-42, https://doi.org/10.1016/j.eps1.2016.02.009, 2016.

Prentice, I. C., Jolly, D., and BIOME 6000 Participants: MidHolocene and glacial-maximum vegetation geography of the northern continents and Africa, J. Biogeogr., 27, 507-519, 2000.

Pueyo, J. J., Sáez, A., Giralt, S., Valero-Garcés, B. L., Moreno, A., Bao, R., Schwalb, A., Herrera, C., Klosowska, B., and Taberner, C.: Carbonate and organic matter sedimentation and isotopic signatures in Lake Chungará, Chilean Altiplano, during the last $12.3 \mathrm{kyr}$, Palaeogeogr. Palaeocl., 307, 339-355, https://doi.org/10.1016/j.palaeo.2011.05.036, 2011.

Quade, J., Rech, J. A., Betancourt, J. L., Latorre, C., Quade, B., Rylander, K. A., and Fisher, T.: Paleowetlands and regional climate change in the central Atacama 
Desert, northern Chile, Quaternary Res., 69, 343-360, https://doi.org/10.1016/j.yqres.2008.01.003, 2008.

Raymo, M. E. and Ruddiman, W. F.: Tectonic forcing of late cenozoic climate, Nature, 359, 117-122, 1992.

Rech, J. A., Pigati, J. S., Quade, J., and Betancourt, J. L.: Re-evaluation of mid-Holocene deposits at Quebrada Puripica, northern Chile, Palaeogeogr. Palaeocl., 194, 207-222, https://doi.org/10.1016/S0031-0182(03)00278-5, 2003.

Robinson, M. M.: New quantitative evidence of extreme warmth in the Pliocene Arctic, Stratigraphy, 6, 265-275, 2009.

Roeckner, E., Bäuml, G., Bonaventura, L., Brokoph, R., Esch, M., Giorgetta, M., Hagemann, S., Kirchner, I., Kornblueh, L., Manzini, E., Rhodin, A., Schlese, U., Schulzweida, U., and Tompkins, A.: The atmospheric general circulation model ECHAM5. Part I: Model description. Rep. 349Rep., Max Planck Institute for Meteorology, Hamburg, 127 pp., 2003.

Roering, J. J., Marshall, J., Booth, A. M., Mort, M., and Jin, Q.: Evidence for biotic controls on topography and soil production, Earth Planet. Sc. Lett., 298, 183-190, https://doi.org/10.1016/j.epsl.2010.07.040, 2010.

Salzmann, U., Williams, M., Haywood, A. M., Johnson, A. L. A., Kender, S., and Zalasiewicz, J.: Climate and environment of a Pliocene warm world, Palaeogeogr. Palaecl., 309, 1-8, https://doi.org/10.1016/j.palaeo.2011.05.044, 2011.

Sarnthein, M.: Sand deserts during glacial maximum and climatic optimum, Nature, 272, 43-46, https://doi.org/10.1038/272043a0, 1978.

Sarnthein, M., Gersonde, R., Niebler, S., Pflaumann, U., Spielhagen, R., Thiede, J., Wefer, G., and Weinelt, M.: Overview of Glacial Atlantic Ocean Mapping (GLAMAP 2000), Paleoceanography, 18, 1030, https://doi.org/10.1029/2002PA000769, 2003.

Schäfer-Neth, C. and Paul, A.: The Atlantic Ocean at the last glacial maximum: objective mapping of the GLAMAP sea-surface conditions, in: The South Atlantic in the late quaternary: reconstruction of material budgets and current systems, edited by: Wefer, G., Mulitza, S., and Ratmeyer, V., Springer, Berlin, 531-548, 2003.

Schaller, M. and Ehlers T. A.: Limits to quantifying climate driven changes in denudation rates with cosmogenic radionuclides, Earth Planet. Sc. Lett., 248, 153-167, https://doi.org/10.1016/j.epsl.2006.05.027, 2006.

Schaller, M., von Blanckenburg, F., Veldkamp, A., Tebbens, L. A., Hovius, N., and Kubik, P. W.: A 30000 yr record of erosion rates from cosmogenic $10 \mathrm{Be}$ in Middle European river terraces, Earth Planet. Sc. Lett., 204, 307-320, 2002.

Schwalb, A., Burns, S., and Kelts, K.: Holocene environments from stable isotope stratigraphy of ostracods and authigenic carbonate in Chilean Altiplano Lakes, Palaeogeogr. Palaeocl., 148, 153168, https://doi.org/10.1016/S0031-0182(98)00181-3, 1999.

Shen J., Liu X. Q., Wang S. M., and Matsumoto R.: Palaeoclimatic changes in the Qinghai, Lake area during the last 18,000 years, Quatern. Int., 136, 131-140, https://doi.org/10.1016/j.quaint.2004.11.014, 2005.

Shen C., Liu K., Tang L., and Overpeck J. T.: Quantitative relationships between modern pollen rain and climate in the Tibetan Plateau, Rev. Palaeobot. Palyno., 140, 61-77, https://doi.org/10.1016/j.revpalbo.2006.03.001, 2006.
Siani, G., Colin, C., Michel, E., Carel, M., Richter, T., Kissel, C., and Dewilde, F.: Late Glacial to Holocene terrigenous sediment record in the Northern Patagonian margin: Paleoclimate implications, Palaeogeogr. Palaeocl., 297, 26-36, https://doi.org/10.1016/j.palaeo.2010.07.011, 2010.

Simmons, A. J., Burridge, D. M., Jarraud, M., Girard, C., and Wergen, W.: The ECMWF Medium-Range prediction models development of the numerical formulations and the impact of increased resolution, Meteorol. Atmos. Phys., 40, 28-60, 1989.

Sohl, L. E., Chandler, M. A., Schmunk, R. B., Mankoff, K., Jonas, J. A., Foley, K. M., and Dowsett, H. J.: PRISM3/GISS topographic reconstruction, U.S. Geological Survey Data Series, 419, 6 pp., 2009.

Sowers T., Alley, R. B., and Jubenville, J.: Ice core records of atmospheric $\mathrm{N}_{2} \mathrm{O}$ covering the last 106,000 years, Science, 301, 945-948, 2003.

Stepanek, C. and Lohmann, G.: Modelling mid-Pliocene climate with COSMOS, Geosci. Model Dev., 5, 1221-1243, https://doi.org/10.5194/gmd-5-1221-2012, 2012.

Stine, S. and Stine M.: A record from Lake Cardiel of climate change in southern South America, Nature, 345, 705-708, https://doi.org/10.1038/345705a0,1990.

Szeicz, J. M., Haberle, S. G., and Bennett, K. D.: Dynamics of North Patagonian rainforests from fine-resolution pollen, charcoal and tree-ring analysis, Chonos Archipelago, Southern Chile, Aust. Ecol., 28, 413-422, https://doi.org/10.1046/j.14429993.2003.01299.x, 2003.

Takahashi, K. and Battisti, D.: Processes controlling the mean tropical pacific precipitation pattern. Part I: The Andes and the eastern Pacific ITCZ, J. Climate, 20, 3434-3451, 2007a.

Takahashi, K. and Battisti, D.: Processes controlling the mean tropical pacific precipitation pattern. Part II: The SPCZ and the southeast pacific dry zone, J. Climate, 20, 5696-5706, 2007b.

Tang, L., Shen, S., Liu, K., and Overpeck, J. T.: Changes in south Asian monsoon: new high-resolution paleoclimatic records from Tibet, China, Chinese Sci. Bull., 45, 87-91, https://doi.org/10.1007/BF02884911, 2000.

Thiede, R. C. and Ehlers, T. A.: Large spatial and temporal variations in Himalayan denudation, Earth Planet. Sc. Lett., 374, 256 257, https://doi.org/10.1016/j.epsl.2013.03.004, 2013.

Thomas, A.: The climate of the Gongga Shan range, Sichuan Province, PR China, Arct. Alp. Res., 29, 226-232, 1997.

Uppala, S. M., Kållberg, P. W., Simmons, A. J., Andrae, U., da Costa Bechtold, V., Fiorino, M., Gibson, J. K., Haseler, J., Hernandez, A., Kelly, G. A., Li, X., Onogi, K., Saarinen, S., Sokka, N., Allan, R. P., Andersson, E., Arpe, K., Balmaseda, M. A., Beljaars, A. C. M., van de Berg, L., Bidlot, J., Bormann, N., Caires, S., Chevallier, F., Dethof, A., Dragosavac, M., Fisher, M. Fuentes, M., Hagemann, S., Hólm, E., Hoskins, B. J., Isaksen, L., Janssen, P. A. E. M., Jenne, R., McNally, A. P., Mahfouf, J.-F., Morcrette, J.-J., Rayner, N. A., Saunders, R. W., Simon, P., Sterl, A., Trenberth, K. E., Untch, A., Vasiljevic, D., Viterbo, P., and Woollen, J.: The ERA-40 re-analysis, Q. J. Roy. Meteor. Soc., 131, 2961-3012, 2005.

Valla, P. G., Shuster, D. L., and van der Beek, P. A.: Significance increase in relief of European Alps during mid-Pleistocene glaciations, Nat. Geosci., 4, 688-692, https://doi.org/10.1038/ngeo1242, 2011. 
Van Campo, E., Cour, P., and Huang, S.: Holocene environmental changes in Bangong Co basin (Western Tibet). Part 2: The pollen record, Palaeogeogr. Palaeocl., 120, 49-63, https://doi.org/10.1016/0031-0182(95)00033-X, 1996.

Villagrán, C. and Varela, J.: Palynological Evidence for Increased Aridity on the Cenral Chilean Coast during the Holocene, Quaternary Res., 34, 198-207, https://doi.org/10.1016/00335894(90)90031-F, 1990.

Villa-Martínez, R. Villagrán, C., and Jenny, B.: The last 7500 cal yr B.P. sf westerly rainfall in Central Chile inferred from a high-resolution pollen record from Laguna Aculeo $\left(34^{\circ} \mathrm{S}\right)$, Quaternary Res., 60, 284-293, https://doi.org/10.1016/j.yqres.2003.07.007, 2003.

von Blanckenburg, F., Bouchez, J., Ibarra, D.E., and Maher, K.: Stable runoff and weathering fluxes into the oceans over Quaternary climate cycles, Nat. Geosci., 8, 538-542, https://doi.org/10.1038/ngeo2452, 2015.

Wei, W. and Lohmann, G.: Simulated Atlantic Multidecadal Oscillation during the Holocene, J. Climate, 25, 6989-7002, https://doi.org/10.1175/JCLI-D-11-00667.1, 2012.

Wang, R. L., Scarpitta, S. C., Zhang, S. C., and Zheng, M. P.: Later Pleistocene/Holocene climate conditions of Qinghai-Xizhang Plateau (Tibet) based on carbon and oxygen stable isotopes of Zabuye Lake sediments, Earth Planet. Sc. Lett., 203, 461-477, https://doi.org/10.1016/S0012-821X(02)00829-4, 2002.

Whipple, K. X.: The influence of climate on the tectonic evolution of mountain belts, Nat. Geosci., 2, 97-104, https://doi.org/10.1038/ngeo413, 2009.

Whipple, K. X. and Tucker, G. E.: Dynamics of the stream-power river incision model: Implications for height limits of mountain ranges, landscape response timescales, and research needs, J. Geophys. Res.-Sol. Ea., 104, 17661-17674, 1999.

Whipple, K. X., Kirby, E., and Broecklehurst, S. H.: Geomorphic limits to climate-induced increases in topographic relief, Nature, 401, 39-43, https://doi.org/10.1038/43375, 1999.

Wilks, D. S.: Statistical methods in the atmospheric sciences, 3rd Edn., Academic Press, Oxford, 2011.

Willett, S. D., Schlunegger, F., and Picotti, V.: Messinian climate change and erosional destruction of the central European Alps, Geology, 34, 613-616, 2006.

Wilson, G. S., Barron, J. A., Ashworth, A. C., Askin, R. A., Carter, J. A., Curren, M. G., Dalhuisen, D. H., Friedmann, E. I., Fyodorov-Davidov, D. G., Gilichinsky, D. A., Harper, M. A., Harwood, D. M., Hiemstra, J. F., Janecek, T. R., Licht, K. J., Ostroumov, V. E., Powell, R. D., Rivkina, E. M., Rose, S. A., Stroeven, A. P., Stroeven, P., van der Meer, J. J. M., and Wizevich, M. C.: The Mount Feather Diamicton of the Sirius Group: an accumulation of indicators of Neogene Antarctic glacial and climatic history, Palaeogeogr. Palaeocl., 182, 117-131, 2002.

Wischnewski, J., Mischke, S., Wang, Y., and Herzschuh, U.: Reconstructing climate variability on the northeastern Tibetan Plateau since the last lateglacial - a multi-proxy, dual-site approach comparing terrestrial and aquatic signals, Quaternary Sci. Rev., 30, 82-97, https://doi.org/10.1016/j.quascirev.2010.10.001, 2011.
Wünnemann, B., Mischke, S., and Chen, F.: A Holocene sedimentary record from Bosten lake, China, Palaeogeogr. Palaeocl., 234, 223-238, https://doi.org/10.1016/j.palaeo.2005.10.016, 2006.

Yanhong, W., Lücke, A., Zhangdong, J., Sumin, W., Schleser, G. H., Battarbee, R. W., and Weilan, X.: Holocene climate development on the central Tibetan Plateau: A sedimentary record from Cuoe Lake, Palaeogeogr. Palaeocl., 234, 328-340, https://doi.org/10.1016/j.palaeo.2005.09.017, 2006.

Yanites, B. J. and Ehlers, T. A.: Global climate and tectonic controls on the denudation of glaciated mountains, Earth Planet. Sc. Lett., 325, 63-75, 2012.

Yu, L. and Lai, Z.: Holocene climate change inferred from stratigraphy and OSL chronology of Aeolian sediments in the Qaidam Basin, northeastern Qinghai-Tibetan Plateau, Quaternary Res., 81, 488-499, https://doi.org/10.1016/j.yqres.2013.09.006, 2014.

Zhang, C. and Mischke, S.: A lateglacial and Holocene lake record from the Nianbaoyeze Mountains and inferences of lake, glacier and climate evolution on the eastern Tibetan Plateau, Quaternary Sci. Rev., 28, 1970-1983, https://doi.org/10.1016/j.quascirev.2009.03.007, 2009.

Zhang, J., Chen, F., Holmes, J. A., Li, H., Guao, X., Wang, J., Li, S., Lu, Y., Zhao, Y., and Qiang, M.: Holocene monsoon climate documented by oxygen and carbon isotopes from lake sediments and peat bogs in China: a review and synthesis, Quaternary Sci. Rev., 30, 1973-1987, https://doi.org/10.1016/j.quascirev.2011.04.023, 2011.

Zhang, R., Yan, Q., Zhang, Z. S., Jiang, D., Otto-Bliesner, B. L., Haywood, A. M., Hill, D. J., Dolan, A. M., Stepanek, C., Lohmann, G., Contoux, C., Bragg, F., Chan, W.-L., Chandler, M. A., Jost, A., Kamae, Y., Abe-Ouchi, A., Ramstein, G., Rosenbloom, N. A., Sohl, L., and Ueda, H.: Mid-Pliocene East Asian monsoon climate simulated in the PlioMIP, Clim. Past, 9, 20852099, h ttps://doi.org/10.5194/cp-9-2085-2013, 2013.

Zhang, X., Lohmann, G., Knorr, G., and Xu, X.: Different ocean states and transient characteristics in Last Glacial Maximum simulations and implications for deglaciation, Clim. Past, 9, 23192333, https://doi.org/10.5194/cp-9-2319-2013, 2013.

Zhang, X., Lohmann, G., Knorr, G., and Purcell C.: Abrupt glacial climate shifts controlled by ice sheet changes, Nature, 512, 290294, https://doi.org/10.1038/nature13592, 2014.

Zhisheng, A., Kutzbach, J. E., Prell, W. L., and Porter, S. C.: Evolution of Asian monsoons and phased uplift of the South Asian plateau since Late Miocene times, Nature, 411, 62-66, 2001.

Zhou, W. J., Lu, X. F., Wu, Z. K., Deng, L., Jull, A. J. T., Donahue, D. J., and Beck, W.: Peat record reflecting Holocene climate change in the Zoigê Plateau and AMS radiocarbon dating, Chinese Sci. Bull., 47, 66-70, https://doi.org/10.1360/02tb9013, 2002. 